\title{
Combined impacts of climate and socio-economic scenarios on irrigation water availability for a dry Mediterranean reservoir
}

\author{
João Pedro Nunes ${ }^{\mathrm{a}, \mathrm{b}, *}$, Rita Jacinto ${ }^{\mathrm{a}, \mathrm{c}}$, Jan Jacob Keizer ${ }^{\mathrm{a}}$ \\ ${ }^{a}$ CESAM \& Dept. Environment and Planning, University of Aveiro. Campus Universitário de Santiago, 3810-193 Aveiro, Portugal \\ b CE3C: Centre for Ecology, Evolution and Environmental Changes, Faculty of Sciences, University of Lisbon. Faculdade de Ciências, Universidade de Lisboa, 1749-016 Lisboa, Portugal \\ ' IGOT: Institute for Geography and Territorial Management, University of Lisbon. Rua Branca Edmée Marques, Cidade Universitária, 1600-276 Lisboa, Portugal.
}

\section{H I G H L I G H T S}

- We studied the impacts of future climate and land-use on a Mediterranean reservoir.

- Lower supply reliability results from less rainfall and higher irrigation demands.

- Worsening trophic conditions result mostly from agricultural intensification.

- Future problems are essentially an aggravation of present-day problems.

- The characteristics of water supply systems are essential to assess vulnerability.

\section{A R T I C L E I N F O}

\section{Article history:}

Received 12 October 2016

Received in revised form 19 January 2017

Accepted 20 January 2017

Available online 20 February 2017

Editor: D. Barcelo

\section{Keywords:}

Mediterranean region

Climate change

Land-use change

Irrigation water supply

Water scarcity

\section{G R A P H I C A L A B S T R A C T}

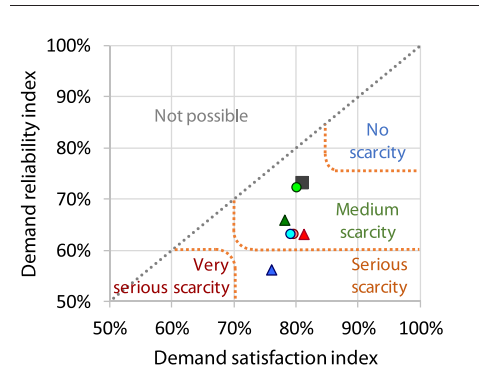

- Baseline
- C-B1

- $S-B 1$

- CS-B1

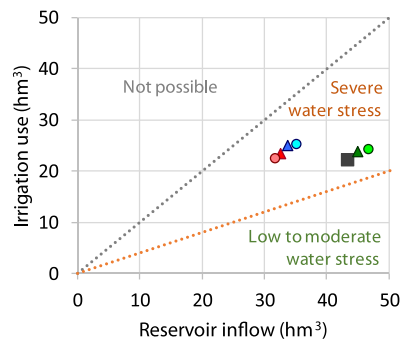

C- climate scenarios

$\mathrm{S}$ - socio-economic scenarios

CS-combined scenarios
Water scarcity index (left) and water exploitation index (right) for baseline conditions and the six future scenarios; dashed lines represent water scarcity and water stress thresholds.

\begin{abstract}
A B S T R A C T
The impacts of climate and associated socio-economic changes on water availability, including supply and demand, quality, and storage volume, were evaluated for the Vale do Gaio reservoir in southern Portugal, located in a dry Mediterranean climate and already under drought stress. The SWAT model was applied with 6 scenarios for 2071-2100, involving two storylines (A1B and B1) with individual changes in climate ( $-9 \%$ rainfall, increasing in winter by +28 to $+30 \%$ ), socio-economic conditions (an increase in irrigation demand by $11 \%$, and a replacement of cereals and pastures by sunflower), and a combination of both. Most future scenarios resulted in lower water availability, due to lower supply $(-19$ to $-27 \%)$ combined with higher irrigation demand ( +3 to $+21 \%$ ). This resulted in more years with limited irrigation supplies (presently: $28 \%$; scenarios: 37 to $43 \%$ ), although limitations were mitigated by lower losses to excess discharge. Land-use changes also decreased quality by increasing P concentrations ( +29 to $+93 \%$ ). Impacts were more severe in scenario A1B than in B1, and in combined changes than in climate or socio-economic changes only. Water availability was resilient to climate change, as impacts led only to a moderate aggravation of present-day conditions. Lower future water availability could be addressed by supply and demand management strategies and, in the most extreme scenario, by water transfers from regional water reserves; water quality issues could be addressed through land-use policies. Results also highlighted the importance of taking the characteristics of water supply systems into account when designing adaptation measures for future changes.
\end{abstract}

() 2017 Elsevier B.V. All rights reserved.

\footnotetext{
* Corresponding author at: CE3C, Faculdade de Ciências da Universidade de Lisboa. Edifício C1, sala 1.4.39, Campo Grande, 1749-016 Lisboa, Portugal. E-mail addresses: jpcnunes@fc.ul.pt (J.P. Nunes), ritajacinto@campus.ul.pt (R. Jacinto), jjkeizer@ua.pt (J.J. Keizer).
} 


\section{Introduction}

Water resources management in the Mediterranean rim of Europe faces several challenges due to variable rainfall patterns and high irrigation demand (EEA, 2012; Iglesias et al., 2011). Future climate in this region is expected to change towards warmer and drier conditions, decreasing available water resources (Collins et al., 2013; García-Ruiz et al., 2011; Kovats et al., 2014). This could be combined with land-use changes as farmers adapt to these drier climate conditions, for example by converting rain-fed to irrigated crops, possibly enhanced or countered by policy measures (Iglesias et al., 2011; Kovats et al., 2014). Such land-use changes could create new challenges for water management, especially as this region is already under water stress conditions (EEA, 2012; Iglesias et al., 2011).

Most research on future water availability in the Mediterranean has focused on the impacts of climate change, addressing water quantity alone (Garrote et al., 2016; Iglesias et al., 2011; López-Moreno et al., 2014; Majone et al., 2016; Mereu et al., 2016; Mourato et al., 2015; Piras et al., 2014; Pulido-Velazquez et al., 2015a; Sellami et al., 2016; Stefanova et al., 2015; Stigter et al., 2014) or combined with water quality (Bangash et al., 2013; Bussi et al., 2014; Carvalho-Santos et al., 2016; Molina-Navarro et al., 2014; Nunes et al., 2013, 2009, 2008; Rodriguez-Lloveras et al., 2016; Serpa et al., 2015; Simonneaux et al., 2015). In general, these studies pointed towards decreasing water availability, a greater seasonal contrast between wet and dry seasons, and, in cases of decreased vegetation cover, increasing sediment and nutrient exports. Models have also been used to examine the impacts of land use change on these parameters (Buendia et al., 2016; Rodriguez-Lloveras et al., 2015). More recently, research began to look into the combined impacts of climate change and associated changes in land use (Carvalho-Santos et al., 2016; López-Moreno et al., 2014; Molina-Navarro et al., 2014; Rodriguez-Lloveras et al., 2016; Serpa et al., 2015; Simonneaux et al., 2015). A key finding of these studies was that land-use changes could have a greater impact on sediment and nutrient exports and, hence, water quality, than changes in climate conditions alone. Ludwig and Roson (2016) introduced the current state of research on these topics. Research on the impacts of combined climate and land use changes has also been performed for other regions of the world (Bussi et al., 2016a, 2016b), and has been pointed as a pressing research need (Li and Fang, 2016).

Models have also been applied to examine Mediterranean water supply systems, taking socio-economic scenarios into account (Paredes-Arquiola et al., 2010; Paredes et al., 2010). Some of these studies have done a combined analysis of water supply vs. demand under climate change scenarios, taking into account the characteristics of the water supply infrastructure. Iglesias et al. (2011) demonstrated an evaluation framework in eastern Spain, using a simple water balance model with management policies to assess the capacity of existing water supply systems to satisfy demand in future climate scenarios and to propose policy recommendations for adaptation. Garrote et al. (2016) expanded a similar analysis to rivers in the Mediterranean rim of Europe, concluding that regional water infrastructures and management policies could be more determinant for climate change vulnerability than future climate scenarios. Girard et al. (2015), Mereu et al. (2016) and Stigter et al. (2014) used similar water balance approaches, applied in more detail, to examine the balance between supply and demand for specific supply systems in respectively southern France, Sardinia, and across Spain, Portugal and Morocco. These studies pointed to a decrease in water supply combined with an increase in irrigation demand, with the vulnerability of a system depending more on its characteristics and on the current balance between supply and demand than on future climate. Finally, López-Moreno et al. (2014) and Pulido-Velazquez et al. (2015b) applied complex process-based modelling approaches in Spain, to a reservoir and an aquifer respectively, concluding that land-use changes could have similar impacts on the demand-supply balance as climate change alone. Both studies conclude that socio-economic changes could be the sufficient for adaptation, the former by a modification to the water supply infrastructure and the latter by land-use change incentives to decrease nitrate leaching.

Not many studies have addressed future changes to water quality in supply infrastructures in the Mediterranean region, resulting from changes in sediment and nutrient inputs, even though such changes could present additional challenges for water supply infrastructures. For a Spanish reservoir, Bangash et al. (2013) applied a simple model based on water production and erosion indices to assess the impacts of climate change on water and sediment inputs, finding a decrease in streamflow as well as sediment input and, hence, reservoir siltation. In contrast, Molina-Navarro et al. (2014), using a complex process-based modelling approach for another Spanish reservoir, found that a synergistic effect between climate and land-use changes could lead to lower water and sediment input and, at the same time, to a deterioration of water quality. Neither study considered the additional impacts of an increased demand for irrigation water in the future.

The results of existing studies point to the importance of the characteristics of the water supply infrastructure and, in particular, its capacity to capture, store and supply sufficient water to meet demands, in determining the vulnerability of water resources to future conditions and in defining adaptation policy options. Similar conclusions have been reached in other regions of the world with a Mediterranean-type climate (Connell-Buck et al., 2011; Medellín-Azuara et al., 2011). Therefore, studies such as that of Garrote et al. (2016) are required, comparing different types of water supply systems (small reservoirs, integrated reservoir networks, aquifers...), different types of water uses (irrigation, domestic or industrial consumption, hydropower production...), and distinct environmental settings (climate, geology...) to evaluate common trends and future challenges.

This work presents an integrated approach to the assessment of the impacts of climate and land-use changes on a Mediterranean irrigation system, the Vale do Gaio reservoir in southern Portugal, where water resources are already under stress from high irrigation demands, mostly during severe drought years. The approach was tested using a subset of existing climate projections for the region. A process-based hydrological model was used, following calibration under present-day conditions, to estimate changes to water supply and demand as well as to sediment and nutrient inputs, caused by: (i) two scenarios of climate change; (ii) two associated scenarios of socio-economic change, each including increased irrigation demands, land-use changes, and lower population; and (iii) two scenarios combining climate and socio-economic changes. Results were evaluated in terms of supply provisioning and reliability, compared with vulnerability thresholds proposed by Iglesias et al. (2011), while the changes in sediment and phosphorus inputs were analysed in terms of reservoir siltation and lifetime, and water quality regulations, respectively.

\section{Methods}

\subsection{Study area}

This work was applied to the case study of the Vale do Gaio reservoir, with a usable volume of $63 \mathrm{hm}^{3}$, located at the end of the Xarrama watershed $\left(528 \mathrm{~km}^{2}\right)$ in the dry region of southern Portugal (Fig. 1). The study area is relatively flat and has shallow soils, mostly Luvisols and Cambisols, overlaying relatively impermeable bedrock of schist and granite (Cardoso et al., 1973). The climate is dry Mediterranean, with rainfall concentrated in autumn and winter. Annual precipitation averages $595 \mathrm{~mm}$ but it is highly variable, ranging from 330 and $1140 \mathrm{~mm}$ between 1981 and 2010 , so that severe droughts occur regularly, the last two in 20032005 and 2011-2012. These factors make irrigation an attractive option for agriculture, especially for growing crops during the dry summer season but also to limit the impacts of possible droughts. However, current agricultural land use is predominantly rainfed, consisting of a combination of pastures and winter cereals on croplands, and pastures underneath 
open forest of Mediterranean evergreen cork and holm oaks ("montado" landscape; EEA and Communities, 2002). Treated wastewater from the city of Évora is discharged in the Xarrama river.

Besides Vale do Gaio, there are several other reservoirs in the Xarrama river but these have little capacity and supply small irrigation areas. The most important of these is São Brissos ( $0.6 \mathrm{hm}^{3}$ volume), located immediately downstream from the Flor da Rosa station (Fig. 1). At present, the Vale do Gaio reservoir is mostly used to irrigate 1938 ha of rice fields that are part of the Sado Valley Hydroagriculture System, with an average water use of $22.1 \mathrm{hm}^{3} \mathrm{yr}^{-1}$ between 2003 and 2012. The reservoir is equipped with a hydroelectric station, only active when there is excess water, and which currently accounts for c. $8 \%$ of total water use. Water quality in the Vale do Gaio reservoir is eutrophic and faces important problems due to phosphorus contamination, as is the case for many reservoirs in the region (Diogo, 2008). Despite this, algal growth seems to be limited by phosphorus in spring, during the optimal period for algal blooms (APA, 2014a; Diogo, 2008).

Recent development plans foresee an increase in the irrigated area with 944 ha of olive groves. This area would be supplied from Vale do Gaio but linked to the Alqueva Multi-Purpose Infrastructure (Fig. 1), i.e. a system where the Alqueva reservoir (the largest in Europe) would act as a centralized water reserve to feed smaller reservoirs during droughts, guaranteeing supplies for up to 3 years (Domingos et al., 2013). This infrastructure is also envisaged for climate change adaptation of the wider region. However, Vale do Gaio would not be part of the Infrastructure itself, i.e. water from Alqueva would only be available after supplying other systems in the Infrastructure; and being at the western end of the water transport system, it is unclear (and not defined in public information about the infrastructure) if additional water would be available during severe droughts.

\subsection{Hydrological and water quality modelling}

This work applied the Soil and Water Assessment Tool (SWAT) version 2010 (Neitsch et al., 2011), a process-based ecohydrological model, to the Xarrama river basin and the Vale do Gaio reservoir. The model was also used to simulate future climate-induced changes to irrigation water demands outside the study area. SWAT is an eco-hydrological model, capable of simulating regional-scale watersheds for several decades with reasonable temporal (daily) and spatial resolution (several sub-basins with individual combinations of land-use, soil and slope class inside) without excessive computing requirements. The model is driven by climate, land management operations, and external inflows and outflows such as wastewater discharges or irrigation demands. Relevant simulated processes include vegetation growth (including the impacts of temperature and available water), runoff and baseflow generation and streamflow routing, sediment and nutrient exports and routing, and reservoir water, sediment and nutrient balance. In spatial terms, SWAT is a semi-distributed model; the study area is divided into sub-watersheds, each subdivided into abstract hydrological response units, i.e. areas with a homogenous combination of land use, soil and slope.

SWAT was applied to the study area using a $90 \mathrm{~m}$ resolution digital terrain model (Jarvis et al., 2006), the CORINE Land Cover 2000 $1: 100,000$ map (EEA, 2002) and the FAO 1:1,000,000 soil map (Cardoso et al., 1973). The watershed was subdivided into ten sub-watersheds, with areas ranging between 13 and $92 \mathrm{Km}^{2}$. While the scale of landcover and topography were comparable, the scale of the soil map was much coarser (equivalent to a $500 \mathrm{~m}$ resolution); however, not only is this sufficient for soil representation in hydrological modelling (Booij, 2003), but also sufficiently small represent soil spatial variability within each sub-watershed.

Vegetation parameters were taken from the SWAT database (Neitsch et al., 2010) or, when missing for Mediterranean crops, from Nunes et al. (2008). Agricultural management information was taken from existing agricultural surveys and manuals (INE, 2011; INIA, 2000). Soil parameters were taken from Cardoso (1965), and modified according to a field analysis of soil depth and texture as described by Serpa et al. (2015). The Vale do Gaio reservoir, wastewater discharges from the city of Évora, other smaller inflows and impoundments, and
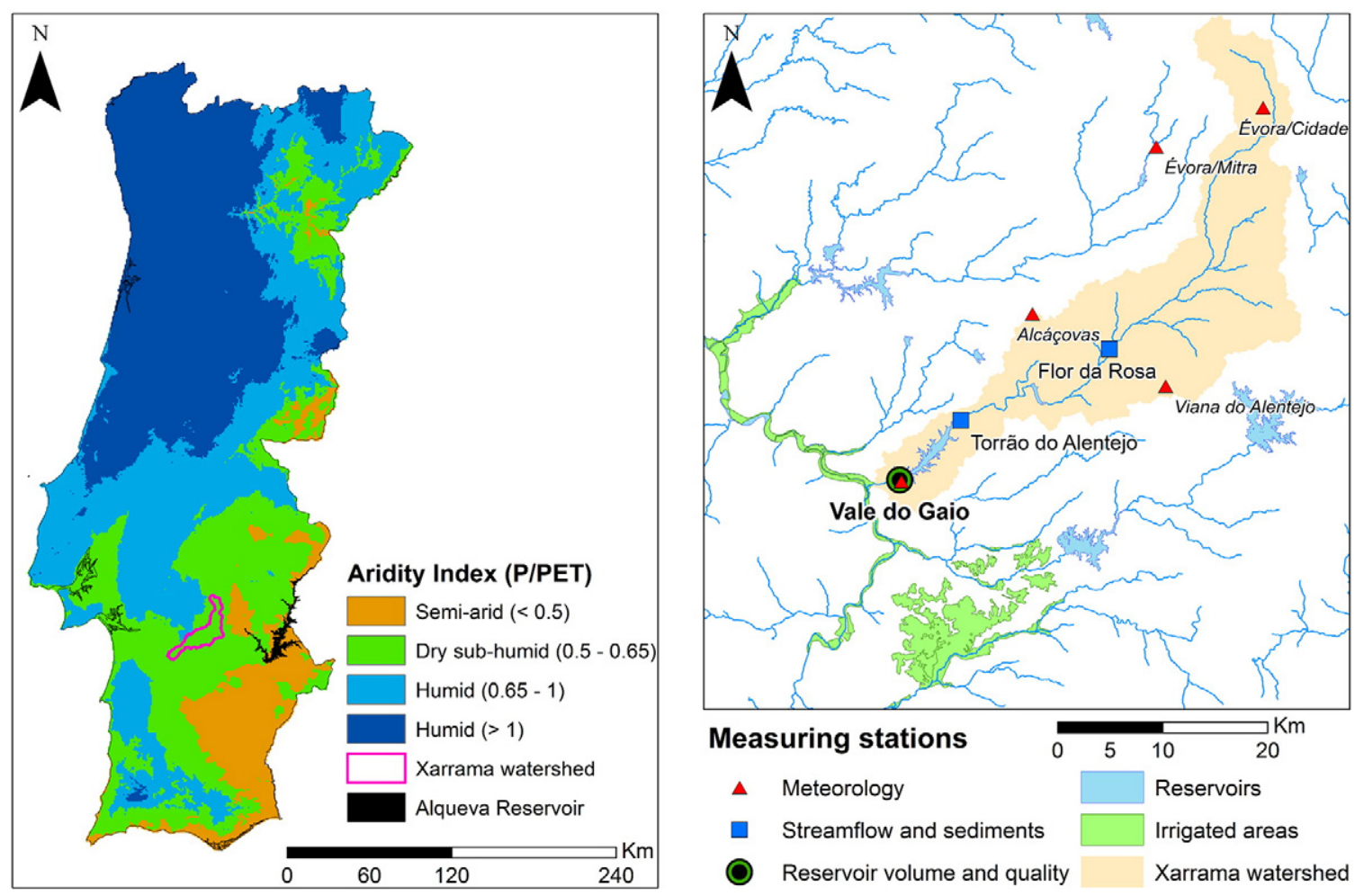

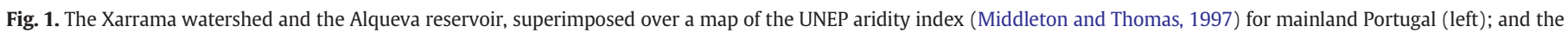
Xarrama river, Vale do Gaio reservoir, nearby irrigated areas in the Sado Valley Hydroagriculture System, and hydroclimatological measuring network (right). 
irrigation demands were parameterized using data from national water infrastructure databases (APA, 2014a, 2014b).

Hydroelectric production only occurs whenever there is storage excess, but the maximum turbine discharge capacity is $4.8 \mathrm{~m}^{3} \mathrm{~s}^{-1}$. Therefore, hydroelectric water consumption was calculated as the amount of reservoir discharge below this threshold, assuming that hydropower was generated whenever there was opportunity; this water consumption was still considered reservoir outflow.

Irrigation demands were assumed to be a constant value per month. This was considered as a valid assumption for this study area, since the data shows a constant per area irrigation of 1090-1200 $\mathrm{mm} \mathrm{yr}^{-1}$ except in years with low reservoir water storage; inter-annual variations were linked with changes in irrigated area (APA, 2014a). The low soil water holding capacity (Serpa et al., 2015) combined with cultivation during the dry season limits the amount of water supplied by rainfall for irrigated crops. Actual irrigation is, however, simulated as varying between years, as it combines a constant demand with variable supply depending on reservoir storage volume.

The model was driven with meteorological data from 5 stations (Fig. 1), obtained from local and national climate databases (APA, 2014a; UÉ, 2014). The period between 1971 and 1979 was used for model spin-up, and the period between 1980 and 2013 for model calibration and validation. Model calibration-validation was based on:

- hydrometric data from 2 hydrometric stations (APA, 2014a), where sediment concentration was measured occasionally and, in the case of the Flor da Rosa station, turbidity was monitored continuously (Fig. 1);

- monthly data on water volume, inflows, outflows, uptakes for irrigation and phosphate concentrations in the Vale do Gaio reservoir; and

- evapotranspiration and soil water data for open cork oak forest with pasture from the Mitra 2 eddy-covariance station, located near the Évora/Mitra in Fig. 1 (Gilmanov et al., 2007; Serpa et al., 2015).

The sediment concentration data at the Torrão do Alentejo station (Fig. 1) were used to build sediment rating curves (Lane et al., 1997) so as to estimate monthly sediment yields from streamflow data (more information in the supplementary material).

The model calibration in this study was heavily based on the prior parameterization of SWAT by Serpa et al. (2015) for the Guadalupe experimental catchment, which is a $4.4 \mathrm{~km}^{2}$ headwater catchment of the Xarrama basin, located near the Évora/Mitra station (Fig. 1). The present calibration process involved three steps:

- Surface processes such as evapotranspiration, soil water dynamics, runoff and erosion in pasture adapted calibrated parameter values from Serpa et al. (2015), which calibrated them using data collected from small bounded plots, including continuous soil moisture measurements and collection of runoff and sediments after rainstorms (2011-2014).

- Erosion in other landcovers, nitrogen and phosphorus exports were calibrated with average annual values for Mediterranean regions (Cerdan et al., 2010; Rial-Rivas, 2007); evapotranspiration, leaf area index and soil water were further validated for the Évora/Mitra station (2004 to 2008).

- Streamflow and sediment yield were calibrated using daily and monthly data from the two above-mentioned hydrometric stations, by modifying only stream and hydrogeological parameters; this was done using a split-sample approach, with the Torrão station for calibration (data between 1980 and 2001) and Flor da Rosa for validation (data between 2001 and 2010).

- Reservoir water balance, irrigation demands and phosphorus loads were not calibrated but merely validated, in the first two cases using the monthly data for volume, outflows and irrigation extractions (1980 to 2012) and in the latter case using the monthly measurements (2000 to 2008) but focussing on mass instead of concentrations to limit the propagation of errors from volume simulations.

The performance of SWAT was evaluated following Moriasi et al. (2007), who set model performance threshold for three evaluation criteria. The average percentual model error (PBIAS) measures systematic differences between simulations and observations, with an optimal value close to 0 . The ratio between the Root of the Mean Squared Error and the standard deviation of observations (RSR) measures the scatter of simulations around observations and ranges between the optimal value close to 0 and $+\infty$, with values above 1 representing unacceptable model performance. The Nash-Sutcliffe Model Efficiency index (NSE) is the difference between 1 and the ratio between the variance of the error and that of observations, which measures the relative magnitude between "noise" and "information" in model results; it ranges between $-\infty$ and the optimal value close to 1 , with negative values being unacceptable. Finally, this work also used Pearson's coefficient of determination $r^{2}$, to measure relative model performance, with an optimal value close to 1 .

\subsection{Impact assessment approach}

SWAT was applied to assess the impacts of climate and socio-economic changes for 2071-2100, when compared with baseline conditions for 1971-2000, taken from the observed data; the long-term future period was selected maximize the difference from baseline conditions. As this was a first approach to this subject in this region, a subset of scenarios illustrating a range of climate change impacts was selected instead of aiming for a comprehensive assessment, following the approach by Serpa et al. (2015).

Scenarios were made for two socio-economic storylines, A1B and B1 (Nakicenovic and Swart, 2000). The A1B storyline leads to more severe climate change, reflecting economic growth in a globalized economy; it was chosen so that climate scenarios and model results could be compared with those resulting from EU project ENSEMBLES (van der Linden and Mitchell, 2009), providing some comparability with other studies at the expense of using a more severe scenario such as A1F1. The B1 storyline was selected to provide a less extreme scenario, reflecting a focus on sustainability, while maintaining the globalization assumption. When compared with more recent climate scenarios (Representative Concentration Pathways - RCP), B1 is equivalent to the average scenario RCP4.5, while $\mathrm{A} 1 \mathrm{~B}$ is equivalent to a more severe scenario RCP6 (van Vuuren et al., 2012); for more recent socio-economic scenarios (Shared Socioeconomic Pathways - SSP), B1 is equivalent to a low challenge for mitigation and adaptation SSP1, while A1B might be considered to have intermediate challenges as in SSP2 (O'Neill et al., 2014). The following scenarios were built based on each storyline:

- scenarios C-A1B and C-B1: climate changes only, with a separate climate forcing for each scenario;

- scenarios S-A1B and S-B1: socio-economic changes only, including a single estimate of future irrigation demand for both scenarios, and separate land use and population change estimates for each scenario; and

- scenarios CS-A1B and CS-B1: a combination of all climate and socioeconomic changes described above.

SWAT was then used to assess the impacts of these scenarios on water availability for the Vale do Gaio reservoir, in terms of water supply, sediment loads, and phosphorus concentrations. Impacts on water supply were assessed using the water scarcity index (Iglesias et al., 2011; Martin-Carrasco and Garrote, 2007) and the water exploitation index (Alcamo et al., 2003; EEA, 2012). The water scarcity index measures the capacity of the system to supply demands, by comparing a demand satisfaction index (ratio between supplied water and total water 
demand) with a demand reliability index (ratio between supplied water in years satisfying at least $85 \%$ of demand and total water demand). The water exploitation index measures the pressure of demand over existing resources (ratio between supplied water and inflows). Impacts on sediment loads were assessed using the reservoir loss of volume due to siltation, calculated by comparing design volume with annual sediment deposition volume, which, in turn, was estimated from sediment inflows, with SWAT calculating sediment trapping from concentration in the reservoir, and equilibrium concentration and a settling rate (Neitsch et al., 2011) and considering an average bulk density of $1.113 \mathrm{~g} \mathrm{~cm}^{-3}$ (de Vente et al., 2006). Impacts on phosphorus concentrations were assessed by comparing median concentrations with the Portuguese threshold for good water quality status in southern reservoirs under the Water Framework Directive (WFD; INAG, 2009), i.e. an average annual $\mathrm{P}$ concentration below $0.07 \mathrm{mg} \mathrm{L}^{-1}$.

\subsection{Scenario design}

Climate scenarios were taken from the work of Serpa et al. (2015), who: (i) applied a predictor transformation approach to generate future seasonal rainfall scenarios from mean sea level pressure estimates made by the ECHAM5 Global Circulation Model for 2071-2100; (ii) used the fragments method to downscale seasonal rainfall predictions to daily predictions, by determining future daily rainfall in a given month using historical data for a month with similar rainfall characteristics; and (iii) used the delta change method (Hay et al., 2000) to estimate daily temperatures for the $\mathrm{A} 1 \mathrm{~B}$ and $\mathrm{B} 1$ scenarios $\left(+2.2\right.$ and $+1.1^{\circ} \mathrm{C}$, respectively). These scenarios were made for the Évora/Cidade station (Fig. 1); in this work, they were extended to the other meteorological stations based on linear regression equations calculated from historical data. These scenarios were introduced directly in SWAT as climatic input data for the model; also, calculated changes to potential evapotranspiration were used to simulate changes to current water demands.

The two climate scenarios led to almost identical decreases in annual rainfall $(-9.3 \%)$, reflecting lower rainfall in autumn and spring compensated by higher rainfall in winter $(+29.9 \%$ in C-A1B and $+28.3 \%$ in C-B1). The differences between them were more apparent in interannual rainfall variability (Fig. 2), with especially extreme rainfall years decreasing in frequency. This is in agreement with the results of the ENSEMBLES project for this region (van der Linden and Mitchell, 2009) and does not contradict the more recent results for scenario RCP8.5, where Mediterranean regions are an exception to the global trend of increasing wet extremes frequency (Collins et al., 2013). However, the decrease in variability could also result from the selected downscaling method, an issue which is further explored in the discussion. The two scenarios also differed markedly in potential evapotranspiration (PET), which increased more in C-A1B $(+5.7 \%)$ than C-B1 $(+3.5 \%)$ due to the higher temperatures.

Socio-economic changes consisted of three sub-scenarios focusing on changes to irrigation water demand, land use, and population.

For irrigation, the same scenario was used in both socio-economic storylines, involving the foreseen increase of the irrigated area with 944 ha of olive trees described above. This additional demand was assumed to be covered by the Vale do Gaio reservoir, as the above-mentioned supplies from the Alqueva Multi-Purpose Infrastructure are not guaranteed. A specific SWAT application for this new irrigated area was made using present-day and future climate conditions, to estimate impacts on reservoir water demands. This scenario led to an increase of irrigation water demand between July and September (see S-A1B and SB1 Fig. 2). These increases, however, were much smaller than the increase in irrigated area ( $+11 \%$ vs. $+49 \%$ ), as olive groves have lesser water requirements than currently existing rice fields. However, both climate scenarios also led to increased irrigation demands between May and August (Fig. 2), due to higher PET and lower rainfall, and these increases were higher in C-A1B $(+5.9 \%)$ than in C-B1 $(+3.4 \%)$, reflecting different PETs. In consequence, the combined climate-socio- economic scenarios (CS-A1B and CS-B1) had higher irrigation demands than the separate scenarios, and the increases relative to baseline conditions indicated a non-linear effect, which was strongest in storyline A1B, due to the added impact of climate on the new irrigation areas.

Land-use changes followed the scenarios developed by Serpa et al. (2015) for the Guadalupe experimental basin, who downscaled and refined the national level land-use change predictions by Jacinto et al. (2013) based on an analysis of local historical trends. In this study, the scenarios were expanded to the entire watershed, but modified so that the actual amount of land-use change matched the national-level predictions. They involved decreases in the cover of rainfed croplands and pastures ( -73.4 and $-54.3 \%$ in $\mathrm{A} 1 \mathrm{~B}$ and B1), as opposed to increases in the cover of forest $(+19.6$ and $+14.7 \%$ in A1B and B1), olive groves ( $+46 \%$ in both scenarios) and croplands for biofuel production (sunflower; Jacinto et al., 2013; Serpa et al., 2015). The foreseen increase in woodland cover was mainly due to new eucalypt plantations replacing croplands in $\mathrm{A} 1 \mathrm{~B}$, and shrub encroachment of abandoned agricultural fields in B1. These scenarios were then introduced in SWAT using a semi-distributed approach, i.e. by modifying land-use distribution inside the broad land-use classes used in SWAT as well as by replacing crops. More information is available in the supplementary material.

Population changes were taken directly from downscaled projections by Jacinto et al. (2013), which were then refined with foreseen migration rates from rural areas to the city of Évora, based on recent trends. The population densities in the A1B and B1 scenarios were nearly identical, however, pointing to a population decrease of $-4.8 \%$. The population scenarios were used to assess changes in wastewater discharge from the Évora treatment plant, forecasting a decrease of direct P discharge of $-7.3 \%$ which was then directly introduced in SWAT.

\section{Results and discussion}

\subsection{Model performance evaluation}

Table 1 lists the model evaluation parameters for the application of SWAT under baseline conditions, while Fig. 3 compares SWAT simulation results with the measurements for the Vale do Gaio reservoir. Overall, the bulk of the SWAT results were, in absolute terms, "satisfactory" or better following the threshold values set by Moriasi et al. (2007). SWAT results for hydrological variables were "good" or "very good", except for reservoir outflow. The "unsatisfactory" outflow simulations in terms of RSR and NSE reflected inherent limitations of SWAT, as water extractions are defined according to total demands and cannot be adjusted to, for example, meteorological conditions or reservoir storage. This resulted in the simulation of excessive extractions and lower reservoir storage levels, especially in consecutive drought years (e.g. 1992 to 1996, or 2005 to 2010), as also indicated by the relative high PBIAS of storage volume $(-16.2 \%)$. These errors then accumulated in a poor simulation of the monthly patterns of excessive storage and, hence, outflow. Annual outflow predictions, however, should still be reliable, as also suggested by the "very good" PBIAS (2.1\%).

SWAT results for sediment flows and mineral Phosphorus mass in the reservoir were worse than for hydrological variables but were generally satisfactory. Calibration of sediment inflows at the Torrão do Alentejo station was "unsatisfactory", except for the "very good" PBIAS $(-1.2 \%)$. Further calibration of SWAT parameters was not possible due to the considerable uncertainty surrounding the estimated sediment yields, which were derived from a sediment rating curve tested only with streamflow values up to $1.6 \mathrm{~m}^{3} \mathrm{~s}^{-1}$, when monthly streamflow values often exceed $10 \mathrm{~m}^{3} \mathrm{~s}^{-1}$ (Fig. 3) and daily values often exceed $50 \mathrm{~m}^{3} \mathrm{~s}^{-1}$. However, the validation performance was "satisfactory" for the more reliable sediment yields at the Flor da Rosa Station (based on continuous turbidity measurements), as also shown in Fig. 3, indicating acceptable model results for sediment yield. 

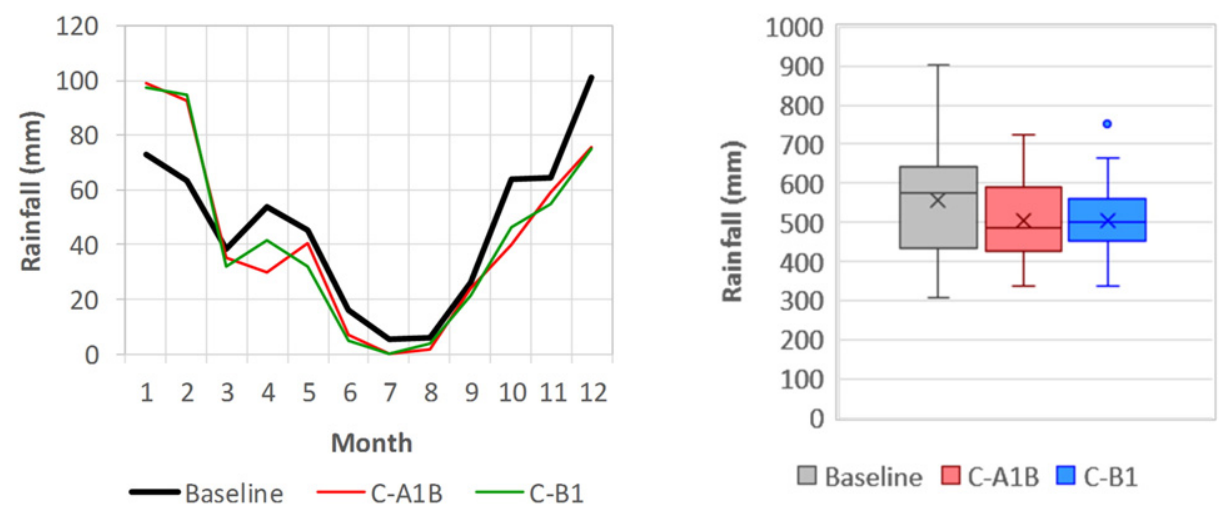

$\square$ Baseline $\square$ C-A1B $\square$ C-B1
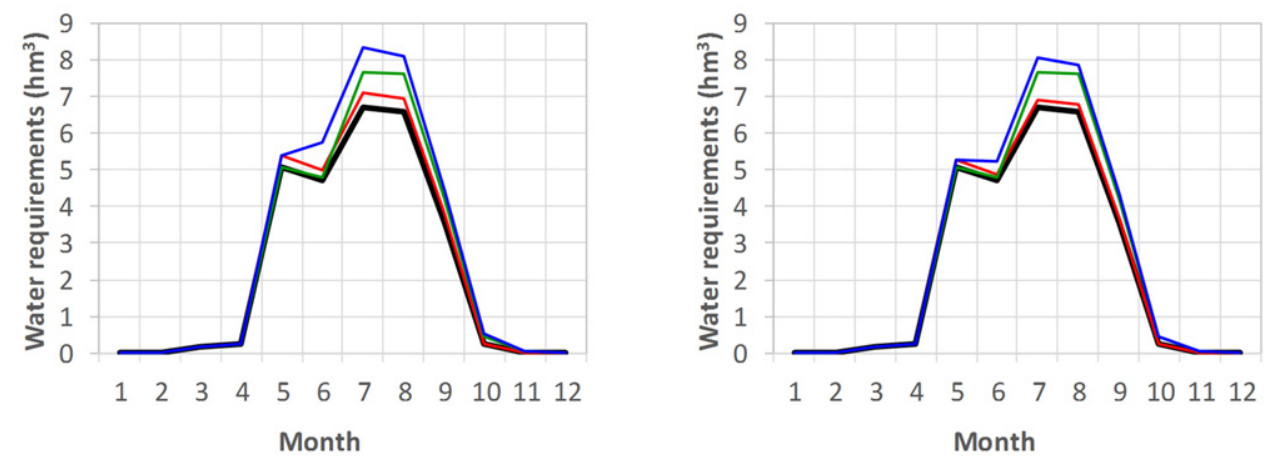

- Baseline - C-A1B - S-A1B - CS-A1B

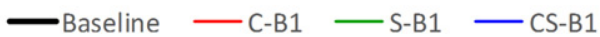

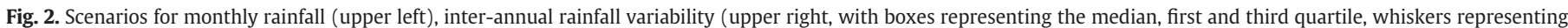

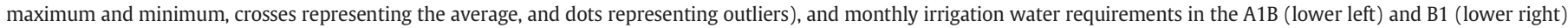
storylines.

\subsection{Impacts on water availability and use}

Table 2 summarizes the scenarios and results for the relevant model parameters, in absolute and relative values (and more information is added in the supplementary material). In all scenarios, evapotranspiration remained relatively constant (between 401 and $422 \mathrm{~mm} \mathrm{y}^{-1}$; Table 2 ), remaining by far the most important water balance component. In the climate change and combined scenarios (C and CS), this led to a higher fraction of rainfall being retained for evapotranspiration, at the expense of other components; it increased from 75 to $76 \%$ of rainfall in the baseline and S scenarios, until 79 to $81 \%$ of rainfall in the $C$ and CS scenarios. This is a characteristic response to climate change of dry Mediterranean catchments with similar land uses (Nunes et al., 2008; Nunes and Seixas, 2011; Serpa et al., 2015).

Furthermore, all climate change scenarios revealed greater impacts on baseflow than on surface runoff, enhancing streamflow irregularity; while baseflow changed from -29 to $-39 \%$, surface runoff change between -12 and $-24 \%$. This also seems to be a typical response for dry Mediterranean systems, especially when soils are shallow and have a low water retention capacity (Nunes et al., 2013, 2008). Worth noting is that the land-use change scenarios led to a slight increase in runoff, particularly surface runoff ( +10 to $+12 \%)$, at the expense of evapotranspiration, baseflow and percolation to deep groundwater. This was due to the lower water use and higher surface runoff generation of the new land uses, especially when converting from pastures and to shrublands.

As for reservoir water balance (Table 2), inflow (including a small direct contribution from rainfall) suffered important changes, with large decreases due to climate change alone $(-25$ and $-27 \%$ in C-A1B and C-B1) and small increases due to land-use change alone ( +3 and $+7 \%$ in S-A1B and S-B1). In the combined scenarios, changes were slightly less important than those for climate alone, especially in storyline B1 ( -23 and $-19 \%$ in CS-A1B and CS-B1), indicating that

Table 1

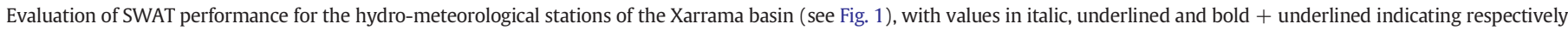
"unsatisfactory", "good" and "very good" model performance according to Moriasi et al. (2007); remaining values indicate "satisfactory" model performance.

\begin{tabular}{|c|c|c|c|c|c|c|c|}
\hline Parameter (monthly values) & Station & Type & Period & PBIAS & RSR & NSE & $r^{2}$ \\
\hline Effective evapotranspiration ${ }^{a}$ & Évora/Mitra & Validation & 2004-2012 & $2.5 \%$ & 0.54 & 0.71 & 0.75 \\
\hline Soil water content $\mathrm{t}^{\mathrm{a}}$ & Évora/Mitra & Validation & 2004-2012 & $\overline{-11.0 \%}$ & $\overline{\mathbf{0 . 5 0}}$ & $\overline{\mathbf{0 . 7 6}}$ & 0.82 \\
\hline \multirow[t]{2}{*}{ Streamflow } & Torrão do Alentejo & Calibration & $1980-2001$ & $8.9 \%$ & 0.45 & $\overline{0.80}$ & 0.86 \\
\hline & Flor da Rosa & Validation & $2001-2012$ & $\overline{-22.2 \%}$ & $\overline{0.50}$ & $\overline{0.76}$ & 0.86 \\
\hline Reservoir inflow & Vale do Gaio & Validation & $1980-2012$ & $\overline{4.5} \%$ & $\overline{0.52}$ & $\overline{0.72}$ & 0.80 \\
\hline Reservoir storage volume ${ }^{a}$ & Vale do Gaio & Validation & $1981-2012$ & $\overline{-16.2 \%}$ & 0.55 & $\overline{0.77}$ & 0.79 \\
\hline Reservoir outflow & Vale do Gaio & Validation & $1981-2012$ & $\overline{2.1 \%}$ & $\overline{0.77}$ & $\overline{0.41}$ & 0.53 \\
\hline Water use (irrigation) ${ }^{\mathrm{a}}$ & Vale do Gaio & Validation & $1980-2012$ & $\overline{5.0 \%}$ & 0.50 & 0.75 & 0.76 \\
\hline \multirow[t]{2}{*}{ Sediment flow } & Torrão do Alentejo & Calibration & $1980-2001$ & $\overline{-1.2} \%$ & $\overline{0.76}$ & $\overline{0.41}$ & 0.69 \\
\hline & Flor da Rosa & Validation & 2001-2012 & $\overline{-15.4 \%}$ & 0.69 & 0.52 & 0.53 \\
\hline Mineral $\mathrm{P}$ in reservoir (mass) & Vale do Gaio & Validation & $2000-2008$ & $-26.8 \%$ & 0.70 & 0.56 & 0.58 \\
\hline
\end{tabular}

a Model performance criteria as for streamflow (Moriasi et al., 2007). 

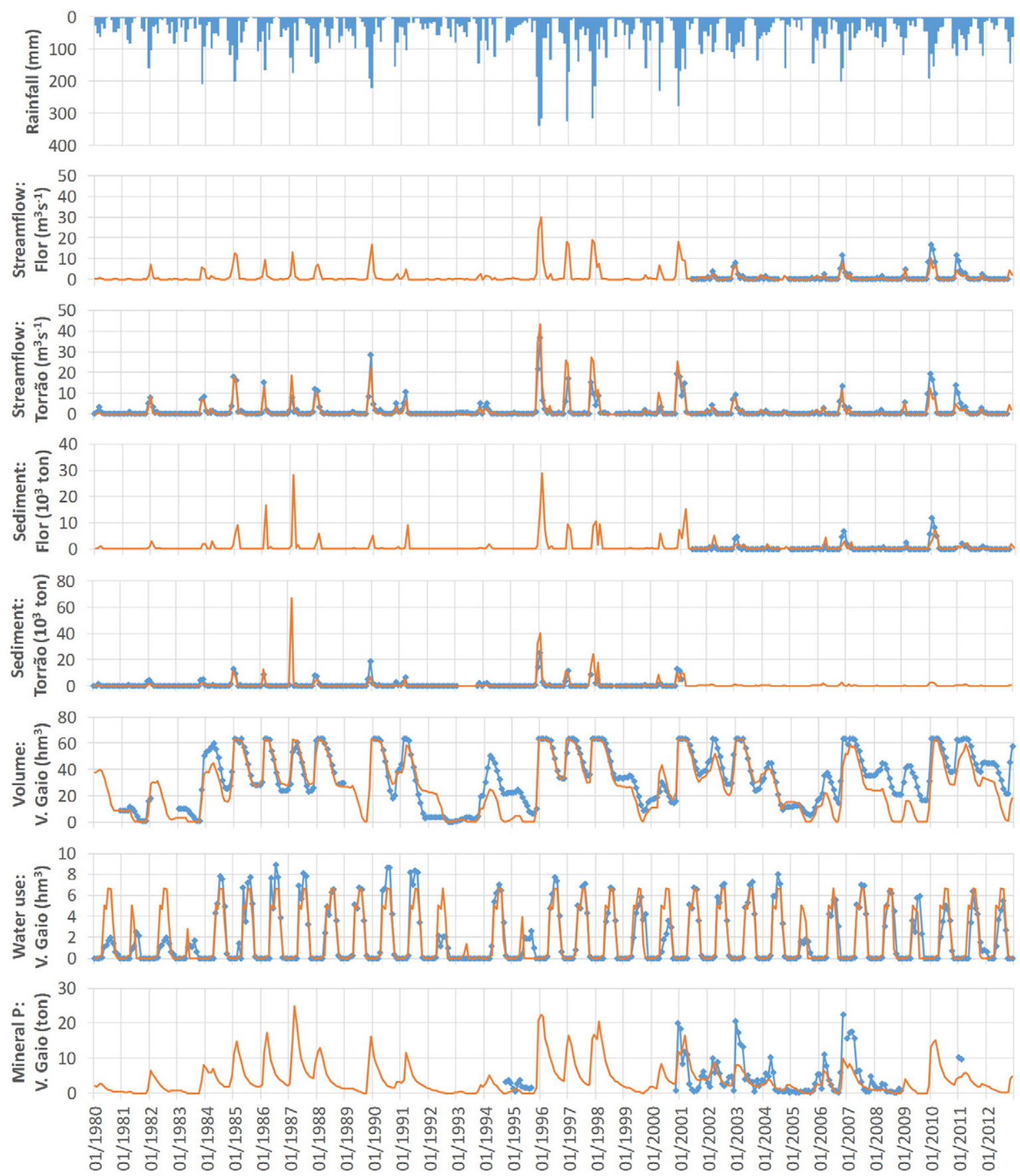

$\rightarrow$ Measured $\longrightarrow$ Simulated

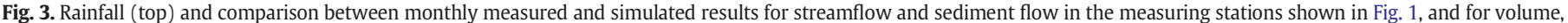
irrigation water consumption and mineral Phosphorus mass in the Vale do Gaio reservoir, for 1980 to 2012.

the increased runoff due to land-use change had a slight mitigating effect on the impacts of lower rainfall.

However, the decreases in inflow were largely absorbed by a decrease in excess discharge during wet years $(-74$ to $-83 \%$ in $\mathrm{C}$ and CS scenarios), which also led to a drop in discharge for hydropower use (from 8 to $4 \%$ of total use). Reservoir losses due evaporation and percolation to deep groundwater only suffered a small decrease, which is explained due to a lower reservoir volume, and hence lower surface and inundated areas; evaporation rate per unit area increased with higher temperature. Changes to irrigation water use followed the increases in irrigation water demand, although at a lower rate, since the increase in demand could not be completely met $(+1$ to $+14 \%$ increase in water use vs. +3 to $+21 \%$ increase in demand). Overall, the decrease in future inflow was therefore counteracted by a more efficient retention of inflows by the reservoir during wet years. A similar tradeoff was found for a Sardinian reservoir by Mereu et al. (2016).

The timing of the reservoir inflow also suffered marked shifts in the climate change and combined scenarios (Fig. 4). The inflow during autumn and winter was delayed one month, reflecting the changes in the seasonal rainfall patterns (Fig. 2) This, combined with the general lower inflow and higher water use, led to a decrease in reservoir volume (values are shown in Table 2), which was most pronounced during the months with the lowest storage levels (August to November) and the months of storage recharge (December and January). In the worstcase scenario CS-A1B, reservoir volumes between September and November were close to $50 \%$ of the present-day values. 
Table 2

Annual climate variables and model results for the baseline conditions and the six future scenarios, in average annual totals and, in brackets, relative changes from baseline.

\begin{tabular}{|c|c|c|c|c|c|c|c|c|}
\hline \multirow[t]{2}{*}{ Parameter } & & \multirow[t]{2}{*}{ Baseline (1971-2000) } & \multicolumn{6}{|c|}{ Future scenarios (2071-2100) } \\
\hline & & & C-A1B & C-B1 & S-A1B & S-B1 & CS-A1B & CS-B1 \\
\hline \multirow[t]{4}{*}{ Climate } & Rainfall & 556.0 & 504.2 & 504.5 & 556.0 & 556.0 & 504.2 & 504.5 \\
\hline & $\left(\mathrm{mm} \mathrm{y}^{-1}\right)$ & & $(-9.3 \%)$ & $(-9.3 \%)$ & - & - & $(-9.3 \%)$ & $(-9.3 \%)$ \\
\hline & $\mathrm{PET}^{\mathrm{a}}$ & 1117.9 & 1182.2 & 1156.9 & 1117.9 & 1117.9 & 1182.2 & 1156.9 \\
\hline & $\left(\mathrm{mm} \mathrm{y}^{-1}\right)$ & & $(5.7 \%)$ & $(3.5 \%)$ & - & - & $(5.7 \%)$ & $(3.5 \%)$ \\
\hline \multirow[t]{10}{*}{ Water balance } & $\mathrm{EET}^{\mathrm{b}}$ & 421.6 & 404.7 & 407.6 & 422.4 & 415.0 & 406.0 & 400.9 \\
\hline & $\left(\mathrm{mm} \mathrm{y}^{-1}\right)$ & & $(-4.0 \%)$ & $(-3.3 \%)$ & $(0.2 \%)$ & $(-1.6 \%)$ & $(-3.7 \%)$ & $(-4.9 \%)$ \\
\hline & Runoff & 82.7 & 62.3 & 60.5 & 85.8 & 89.4 & 64.9 & 67.4 \\
\hline & $\left(\mathrm{mm} \mathrm{y}^{-1}\right)$ & & $(-24.7 \%)$ & $(-26.8 \%)$ & $(3.8 \%)$ & $(8.2 \%)$ & $(-21.5 \%)$ & $(-18.5 \%)$ \\
\hline & - as surface runoff & 53.7 & 42.9 & 41.1 & 59.3 & 59.9 & 47.4 & 46.7 \\
\hline & $\left(\mathrm{mm} \mathrm{y}^{-1}\right)$ & & $(-20.2 \%)$ & $(-23.5 \%)$ & $(10.4 \%)$ & $(11.5 \%)$ & $(-11.7 \%)$ & $(-13.1 \%)$ \\
\hline & - as baseflow & 28.9 & 19.4 & 19.4 & 26.5 & 29.5 & 17.5 & 20.7 \\
\hline & $\left(\mathrm{mm} \mathrm{y}^{-1}\right)$ & & $(-33.1 \%)$ & $(-32.9 \%)$ & $(-8.5 \%)$ & $(1.9 \%)$ & $(-39.6 \%)$ & $(-28.6 \%)$ \\
\hline & Percolation to aquifer & 51.7 & 37.3 & 36.4 & 47.7 & 51.6 & 33.3 & 36.3 \\
\hline & $\left(\mathrm{mm} \mathrm{y}^{-1}\right)$ & & $(-27.9 \%)$ & $(-29.6 \%)$ & $(-7.6 \%)$ & $(-0.2 \%)$ & $(-35.7 \%)$ & $(-29.8 \%)$ \\
\hline \multirow[t]{4}{*}{ Field exports } & Erosion & 0.3 & 0.3 & 0.3 & 0.6 & 0.5 & 0.5 & 0.5 \\
\hline & $\left(\right.$ ton $\left.\mathrm{ha}^{-1} \mathrm{y}^{-1}\right)$ & & $(18.5 \%)$ & $(16.8 \%)$ & $(119.7 \%)$ & $(101.4 \%)$ & $(116.7 \%)$ & $(106.9 \%)$ \\
\hline & P exports & 0.4 & 0.4 & 0.4 & 0.7 & 0.7 & 0.6 & 0.6 \\
\hline & $\left(\mathrm{kg} \mathrm{ha}^{-1} \mathrm{y}^{-1}\right)$ & & $(0.5 \%)$ & $(0.4 \%)$ & $(56.1 \%)$ & $(54.1 \%)$ & $(42.6 \%)$ & $(46.5 \%)$ \\
\hline \multirow[t]{16}{*}{ Reservoir water balance } & Volume $^{\mathrm{c}}$ & 24.6 & 20.9 & 21.4 & 23.8 & 24.8 & 19.2 & 21.7 \\
\hline & $\left(\mathrm{hm}^{3}\right)$ & & $(-15.0 \%)$ & $(-12.7 \%)$ & $(-3.1 \%)$ & $(0.8 \%)$ & $(-21.8 \%)$ & $(-11.8 \%)$ \\
\hline & Inflow $^{d}$ & 43.6 & 32.6 & 31.7 & 45.0 & 46.8 & 33.7 & 35.1 \\
\hline & $\left(\mathrm{hm}^{3} \mathrm{y}^{-1}\right)$ & & $(-25.3 \%)$ & $(-27.2 \%)$ & $(3.3 \%)$ & $(7.4 \%)$ & $(-22.6 \%)$ & $(-19.4 \%)$ \\
\hline & Losses $^{\mathrm{e}}$ & 7.7 & 6.8 & 6.8 & 7.4 & 7.7 & 6.2 & 6.9 \\
\hline & $\left(\mathrm{hm}^{3}\right)$ & & $(-12.1 \%)$ & $(-10.8 \%)$ & $(-3.1 \%)$ & $(0.7 \%)$ & $(-18.9 \%)$ & $(-9.8 \%)$ \\
\hline & Outflow & 11.8 & 2.9 & 3.0 & 11.8 & 12.7 & 2.6 & 3.6 \\
\hline & $\left(\mathrm{hm}^{3} \mathrm{y}^{-1}\right)$ & & $(-75.9 \%)$ & $(-74.5 \%)$ & $(-0.4 \%)$ & $(7.5 \%)$ & $(-77.7 \%)$ & $(-69.3 \%)$ \\
\hline & - as hydropower discharge & 3.4 & 1.4 & 1.3 & 3.2 & 3.7 & 1.2 & 1.5 \\
\hline & $\left(h^{3} y^{-1}\right)$ & & $(-58.3 \%)$ & $(-61.4 \%)$ & $(-5.7 \%)$ & $(9.4 \%)$ & $(-63.4 \%)$ & $(-56.7 \%)$ \\
\hline & - as excess discharge & 8.5 & 1.4 & 1.7 & 8.6 & 9.0 & 1.4 & 2.2 \\
\hline & $\left(h^{3} y^{-1}\right)$ & & $(-82.9 \%)$ & $(-79.7 \%)$ & $(1.7 \%)$ & $(6.7 \%)$ & $(-83.4 \%)$ & $(-74.4 \%)$ \\
\hline & Irrigation demand & 27.3 & 28.9 & 28.2 & 30.3 & 30.3 & 33.0 & 31.7 \\
\hline & $\left(\mathrm{hm}^{3} \mathrm{y}^{-1}\right)$ & & $(5.9 \%)$ & $(3.4 \%)$ & $(11.2 \%)$ & $(11.2 \%)$ & $(21.0 \%)$ & $(16.2 \%)$ \\
\hline & Irrigation use & 22.1 & 23.5 & 22.4 & 23.7 & 24.3 & 25.1 & 25.1 \\
\hline & $\left(h^{3} y^{-1}\right)$ & & $(6.1 \%)$ & $(1.4 \%)$ & $(7.3 \%)$ & $(9.9 \%)$ & $(13.5 \%)$ & $(13.5 \%)$ \\
\hline \multirow[t]{6}{*}{ Reservoir quality } & Sediment inflow & 8.0 & 8.3 & 7.6 & 16.7 & 16.3 & 15.2 & 14.8 \\
\hline & $\left(10^{3}\right.$ ton $\left.\mathrm{y}^{-1}\right)$ & & $(4.3 \%)$ & $(-5.0 \%)$ & $(109.4 \%)$ & $(104.2 \%)$ & $(91.0 \%)$ & $(85.6 \%)$ \\
\hline & $\mathrm{P}$ inflow & 2.0 & 1.9 & 1.9 & 2.9 & 2.9 & 2.5 & 2.7 \\
\hline & $\left(\right.$ ton $\left.\mathrm{y}^{-1}\right)$ & & $(-4.8 \%)$ & $(-4.1 \%)$ & $(47.9 \%)$ & $(47.8 \%)$ & $(27.7 \%)$ & $(34.8 \%)$ \\
\hline & P concentration ${ }^{f}$ & 0.2 & 0.3 & 0.3 & 0.3 & 0.3 & 0.4 & 0.4 \\
\hline & $\left(\mathrm{mg} \mathrm{L}^{-1}\right)$ & & $(29.8 \%)$ & $(28.9 \%)$ & $(52.0 \%)$ & $(46.6 \%)$ & $(92.7 \%)$ & $(85.5 \%)$ \\
\hline
\end{tabular}

a PET: potential evapotranspiration.

b EET: effective evapotranspiration.

c Average annual value.

d Includes streamflow and direct rainfall.

e Includes evaporation from the reservoir surface and percolation from the reservoir bed.

f Median annual value.

Finally, future inflow also reflected the decrease in inter-annual rainfall variability due to climate change (Fig. 2), with both overall ranges and interquartile ranges decreasing markedly (Fig. 5). This shows that changes in annual average values were mostly due to decreases in the number of wet years than in average years, as the median inflow only decreased in the CS scenarios. As a consequence, the number of years with hydropower production was almost halved in the climate change and combined scenarios, explaining the strong decrease in excess discharge and hydropower generation discussed above.

Furthermore, the increase in irrigation water consumption was followed by a decrease to the capacity of reservoirs to satisfy irrigation water demands in drier years (Fig. 5). While demand was met in more than half the years for all scenarios except CS-A1B, there was also an increase in inter-annual variability, with lower demand satisfaction rates during drier years; the 1st quartile satisfaction dropped from a baseline of $72 \%$, to between 59 and $61 \%$ for the C and S scenarios, $55 \%$ for CS-B1, and $47 \%$ for CS-A1. In fact, while very low values could be considered outliers in the baseline scenario, this is not the case in others as they were in line with this higher variability. Scenario CS-A1B showed the least demand satisfaction: demand was not met in more than half of the years, and the 1st quartile was also noticeably lower than that of other scenarios.
However, the most relevant result for water availability was the increase in the number of years where demand satisfaction was below $85 \%$, considered as a threshold for reasonable supply in irrigation (Martin-Carrasco and Garrote, 2007). Baseline conditions and scenario S-B1 showed 8 years of supply restrictions, while in other scenarios they were between 10 and 13, with the largest increase in scenario CS-A1B. These changes to demand satisfaction resulted mostly from lower storage volumes, due to lower average and wet season inflow in the $C$ scenarios (Fig. 5), higher demand during normal years in the S scenarios (Fig. 2), and a combination of both in the CS scenarios. As a result, less water was stored during drought years to satisfy demand. More information can be found in the supplementary material.

\subsection{Impacts on indices of water scarcity and exploitation}

Fig. 6 shows the impacts of all six future scenarios on the indices of water scarcity (focusing on the reservoir, and composed of two indices: demand satisfaction and demand reliability) and water exploitation (focusing on the watershed). Most scenarios led to an important increase in water scarcity, mostly through a decrease in reliability rather than in satisfaction. The only exception was the socio-economic scenario S$\mathrm{B} 1$, where the increase in inflow was enough to counteract the increase 

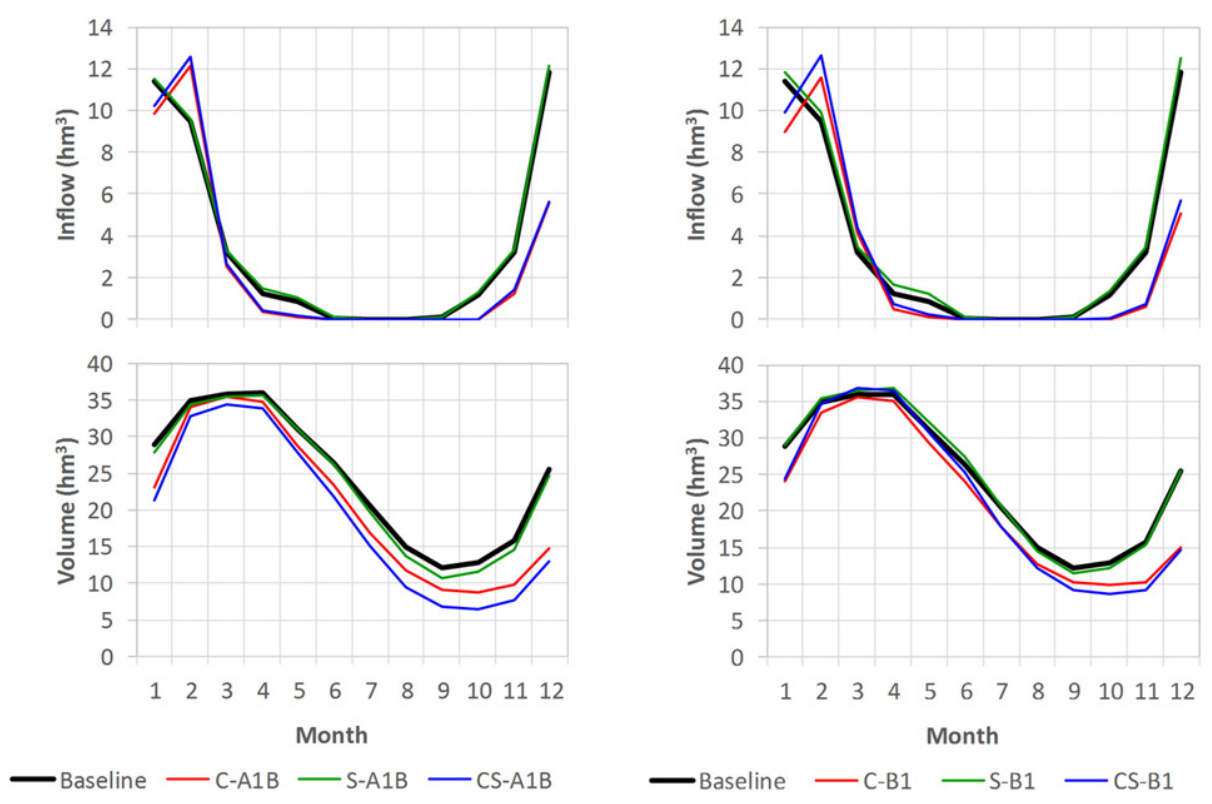

Fig. 4. Monthly reservoir inflow (top) and volume (bottom) for the different scenarios of storylines A1B (left) and B1 (right).

in demand, which led to almost no changes in both indices. Following the thresholds by Iglesias et al. (2011), the Vale do Gaio reservoir presently faces medium water scarcity conditions, and this will not change in the future, except in the case of the combined CS-A1B scenario for which serious water scarcity is predicted; in fact, while in other scenarios satisfaction decreases from 81 to $78 \%$ and reliability decreases from 73 to $63 \%$, CS-A1B has a satisfaction index of $76 \%$ and a reliability index of $56 \%$. This concurred with what was already visible in the inter-annual variability (Fig. 5), where CS-A1B is the only scenario where the median demand satisfaction is under $100 \%$. In terms of the water exploitation index, present-day and future conditions corresponded to severe water stress. However, the climate change and combined scenarios resulted in a marked increase in the fraction of available water resources exploited for use (from a range between 51 and 53\%, to between 71 and 74\%); decreases in inflow had a larger impact than the increases in water demand.

The water scarcity and exploitation indices therefore demonstrated different aspects of future water resources. The scarcity index revealed a clear contrast between the two storylines, i.e.: (i) in the case of the A1B storyline, the socio-economic changes had as much impact as the climate changes, and these impacts were additive when socio-economic and climate changes were combined; in the case of the B1 storyline, the socio-economic changes hardly had any impact, as opposed to the

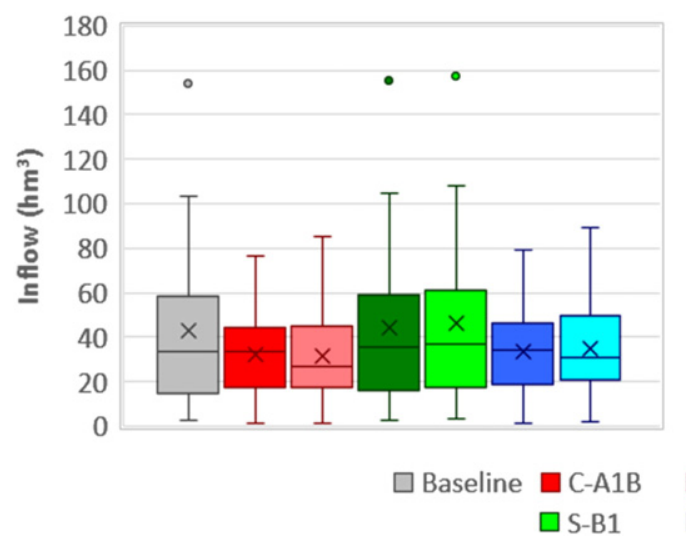

climate changes. The water exploitation index, on the other hand, revealed similar impacts for both storylines and these impacts were mainly due to climate changes, markedly reducing inflow.

Since future changes to the water scarcity index were mostly due to a decrease in demand reliability (and, as such, mainly an issue of supply timing) rather than to a change in total supply, this problem could probably be addressed by multi-year strategies of water supply management. On the other hand, the problems indicated by the exploitation index pointed to the need for measures addressing water supply. These implications for management are further explored below.

\subsection{Impacts on reservoir siltation and trophic state}

Fig. 7 shows the average annual rates of erosion and phosphorus (P) export for each land-use type under baseline and future conditions. In the case of the present-day land-use types, any changes were, by definition, limited to the climate change and combined scenarios ( $\mathrm{C}$ and $\mathrm{CS}$ ); however, changes in erosion and $P$ export revealed similar trends for the individual land-use types, reflecting the predominance of the organic and, thus, particulate fraction in total P exports. These trends differed between land-use types, with climate changes increasing erosion and $\mathrm{P}$ export rates in winter cereals $(+45$ to $+46 \%$ erosion and +30 to $+35 \% \mathrm{P}$ exports), while decreasing them in summer cereals ( -13 to

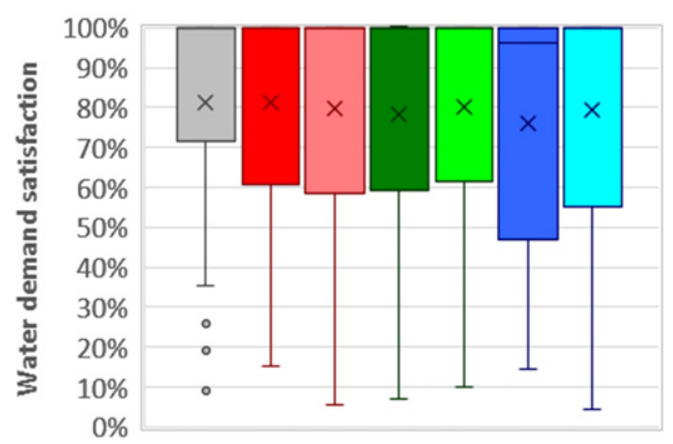

\section{$\square$ C-B1 $\square$ S-A1B \\ $\square$ CS-A1B $\square$ CS-B1}

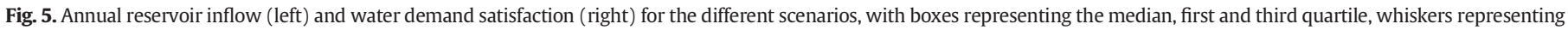

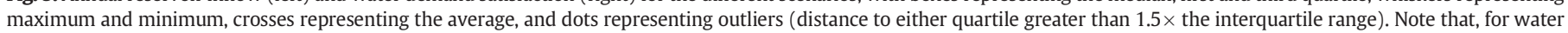
demand satisfaction, the maximum, third quartile and median coincide in all scenarios except CS-A1B. 

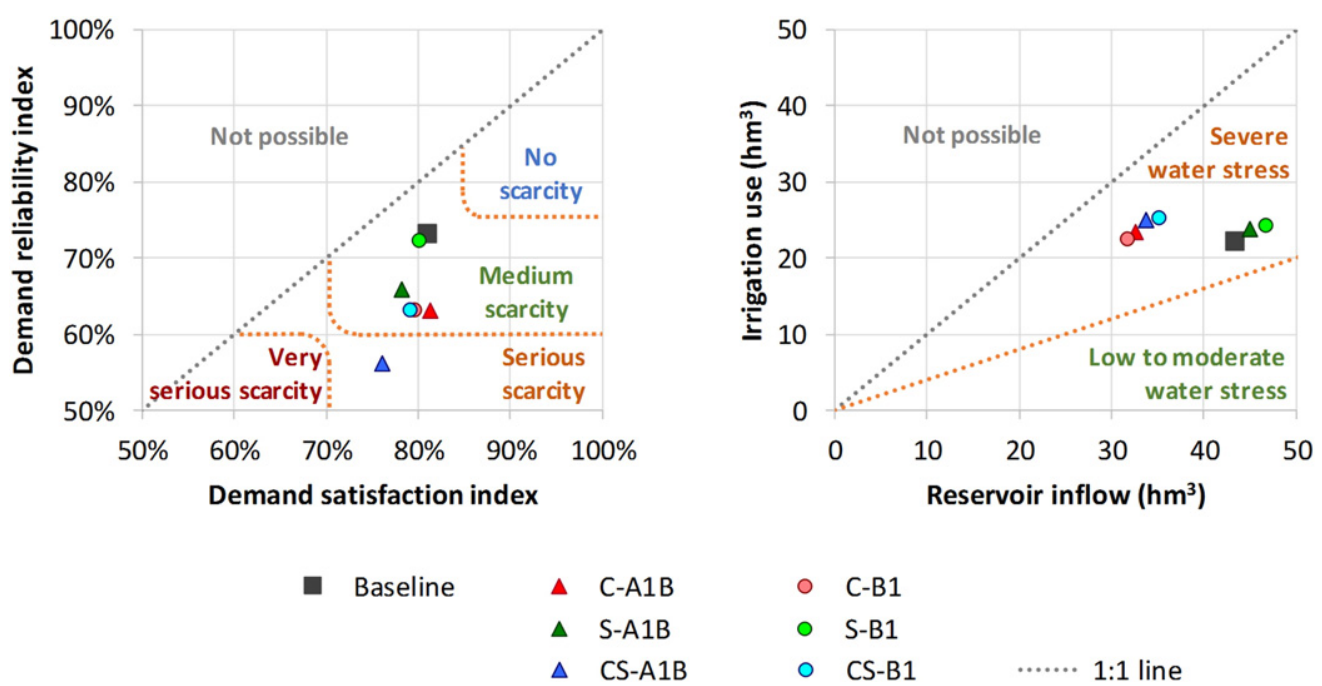

...... 1:1 line

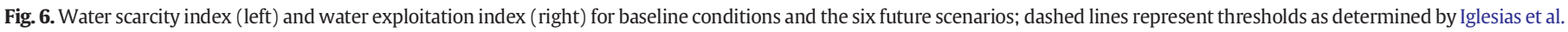
(2011) and Alcamo et al. (2003), respectively.

$-17 \%$ erosion and -22 to $-25 \% \mathrm{P}$ exports), olive groves ( -20 to $-31 \%$ erosion and -19 to $-28 \%$ P exports) and forests. These different trends can be associated with different cover patterns (see the supplementary material for more information). Winter cereals have lower cover during the wet season, precisely when an increase in rainfall is predicted (see Fig. 2); future warmer winters are expected to accelerate vegetation growth and anticipate leaf emergence (by up to one month in scenario A1B), but this is not enough to mitigate this impact. Permanent vegetation such as olive groves and forests, on the other hand, will maintain high cover during the wet season, even if the dryer climate might decrease this somewhat in eucalypts; therefore the lower rainfall leads to a decrease in already low erosion rates. These results concur with those of other studies in the same region and with similar scenarios (Nunes et al., 2013, 2008; Nunes and Seixas, 2011; Serpa et al., 2015).
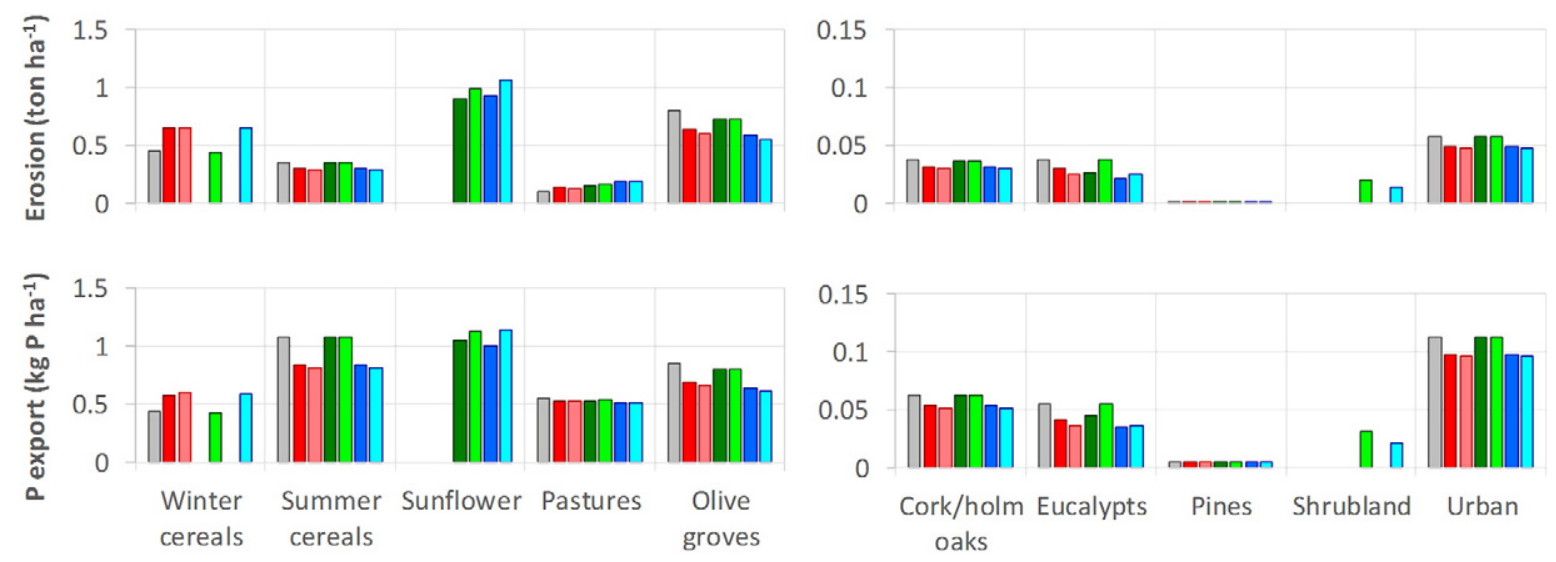

$\square$ Baseline $\square \mathrm{C}-\mathrm{A} 1 \mathrm{~B} \square \mathrm{C}-\mathrm{B} 1 \square \mathrm{S}-\mathrm{A} 1 \mathrm{~B} \square \mathrm{S}-\mathrm{B} 1 \square \mathrm{CS}-\mathrm{A} 1 \mathrm{~B} \square \mathrm{CS}-\mathrm{B} 1$
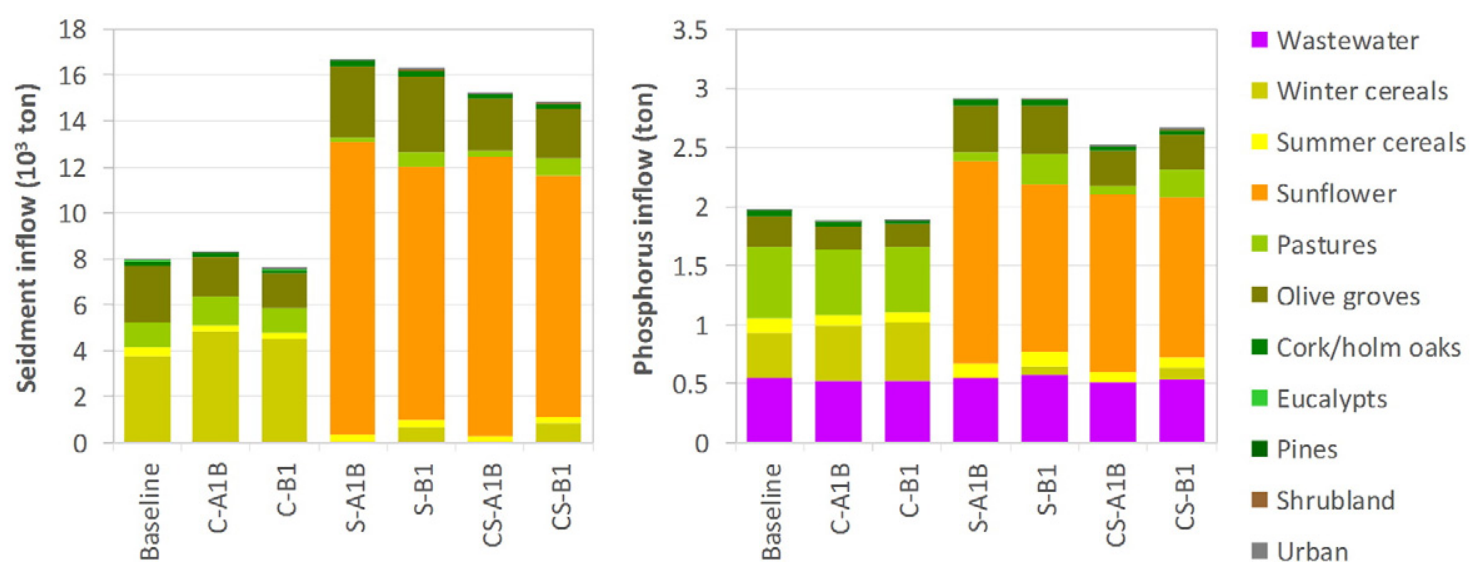

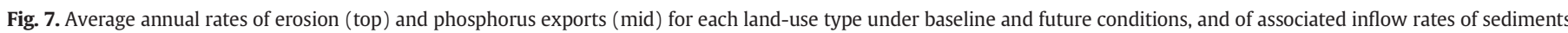
(bottom left) and Phosphorus (bottom right) into the Vale do Gaio reservoir. 
However, differences between land-use types largely defined the differences in erosion and $P$ exports between the scenarios shown in Table 2. Therefore, changes in baseline erosion and $\mathrm{P}$ exports were more important in the $\mathrm{S}$ and CS scenarios than in the C scenarios due mostly to land-use changes (Fig. 7), as was also found by Serpa et al. (2015). Sediment and $P$ inflows to the reservoir revealed the same pattern of changes, but were attenuated by in-stream deposition/retention of eroded sediments and P. Sediment and P inflow changed from -5 to $+4 \%$ and -4 to $-5 \%$ (respectively) in the C scenarios, but +86 to $+109 \%$ and +28 to $+48 \%$ (respectively) in the $S$ and CS scenarios. The differences between the CS and S scenarios were due to the lower water inflows (see Table 2). The predominant role of land-use change in projected sediment and $\mathrm{P}$ inflows can easily be seen in Fig. 7, since in the S and CS scenarios, the newly added sunflower culture was the dominant source of sediment and $\mathrm{P}$ inflows. Wastewater from the Évora treatment plant was also an important source of $P$ inflows, but it changed little from baseline to projected conditions, independent of the scenarios.

The projected changes in sediment inflow rates had no noticeable consequence for reservoir siltation. The sediment inflows in present day conditions and under climate change scenarios (C) led to a loss of c. $0.01 \%$ reservoir volume per year, while those of the land-use change scenarios ( $\mathrm{S}$ and $\mathrm{CS}$ ) led to a loss of c. $0.02 \%$; in both cases, reservoir lifetime was measured in thousands of years. These minor impacts not only reflect the relatively low erosion rates, which are in line with typical observations in Mediterranean regions (Cerdan et al., 2010), but also the large volume of Vale do Gaio. To illustrate the importance of a large volume, the reservoir of São Brissos (with a volume that is c. 1\% of that of the Vale do Gaio) is foreseen to lose $0.7 \%$ of its storage volume per year under baseline conditions but increasing to $1.4 \%$ per year in the CS scenarios. The land-use change scenarios ( $\mathrm{S}$ and CS) did nonetheless have consequences for land degradation, as erosion rates in sunflower fields was close to the tolerable rate of 1 ton ha ${ }^{-1} \mathrm{y}^{-1}$ (Verheijen et al., 2012), much higher than the rates in the landcovers they replaced ( 0.1 to 0.2 ton $\mathrm{ha}^{-1} \mathrm{y}^{-1}$ in pastures and 0.4 to 0.6 ton ha ${ }^{-1} \mathrm{y}^{-1}$ in winter cereals). This finding is corroborated by the results of Serpa et al. (2015). Finally, changes to inter-annual distribution followed those of rainfall and streamflow, but also changed in proportion to changes in erosion rates; variability decreased in the climate change scenarios and increased in both the landuse change and the combined scenarios, although to a smaller degree in the latter (more information in the supplemental material).

The increases in $\mathrm{P}$ inflow in the $\mathrm{S}$ scenarios $(+48 \%$ in both storylines) produced analogous increases in $\mathrm{P}$ concentration within the reservoir ( +52 and $+47 \%$ in S-A1B and S-B1). In contrast, the increases in $\mathrm{P}$ concentration in the climate change scenarios $(+30$ and $+29 \%$ in C-A1B and C-B1, +93 and $+86 \%$ in CS-A1B and CS-B1) were much larger than could be expected from changes in inflow alone $(-5$ and $-4 \%$ in C-A1B and C-B1, +28 and $+35 \%$ in CS-A1B and CS$\mathrm{B} 1$ ), and were to a large extent caused by lower reservoir volumes (Table 2). These increases were especially larger in the winter months, when higher P inflows were combined with lower water storage. They were also much higher in years of exceptionally low water storage, with average annual concentrations occasionally reaching values well above $1 \mathrm{mg} \mathrm{L}^{-1}$ in all scenarios, despite the typical annual concentration range between 0.3 and $0.4 \mathrm{mg} \mathrm{L}^{-1}$ (Table 2); see the supplementary material for more information. Even under baseline conditions, however, P concentrations were well above the WFD threshold of $0.07 \mathrm{mg} \mathrm{L}^{-1}$. While results did not allow the simulation of future rations between nitrogen and phosphorus, this increase in P loads would counteract the existing P limitation in spring, and possibly lead to even larger algal growth and the worsening of an already-high trophic state.

\subsection{Overall comparison with other studies}

In general terms, the predicted impacts of the scenarios presented here for the Xarrama watershed concur with those for the
Mediterranean in general and this region in specific (Molina-Navarro et al., 2014; Mourato et al., 2015; Nunes et al., 2013, 2008; Serpa et al., 2015; Simonneaux et al., 2015): decrease and greater seasonal contrast in streamflow, and increase in soil losses mostly due to land-use evolution associated with climate change. It is interesting, however, to compare watershed-scale and reservoir-scale impact assessments. For example, Serpa et al. (2015) found that socio-economic scenarios usually had small impacts on water resources at the watershed scale when compared with climate scenarios, while this study found that they had large impacts on water resources due to increased irrigation water demand. The same authors also found that land-use change scenarios caused important erosion problems at the watershed scale, while this study found that such enhanced erosion rates only had small consequences for reservoir siltation due to the relatively large volume of the Vale do Gaio reservoir.

This highlights that the predicted impacts of climate change at the watershed scale, while consistent across multiple studies for this region, cannot be taken by themselves as reliable indicators of impacts on water supply systems. This work confirms earlier studies that the characteristics of the water supply system should play a crucial role in global change impact and vulnerability assessments. Such characteristics include water demand (Mereu et al., 2016; Stigter et al., 2014), reservoir volume and drained area (López-Moreno et al., 2014; Mereu et al., 2016) and water management policies (Garrote et al., 2016; Iglesias et al., 2011).

While climate change scenarios are relatively consistent across impact assessments, socio-economic scenarios definitely are not, even for the same storyline, as they depend both on the specific edaphoclimatic context as well as on volatile societal changes (Stigter et al., 2015). This has led to the creation of different hypothetical scenarios, which can be considered equally valid when based on past trends, planned changes, and consistent future storylines. For example, López-Moreno et al. (2014) propose an alternative land-use scenario that foresees agricultural abandonment which then results in a decrease water of demand and supply, while Molina-Navarro et al. (2014) present a range of different land-use scenarios that have contrasting consequences for reservoir trophic state, mainly depending on agricultural abandonment or intensification. The lack of important impacts of land-use changes on water supply reported here can be attributed to a combination of shallow soils and impervious bedrock preventing tree roots development. A similar explanation was suggested by Carvalho-Santos et al. (2016) and Hawtree et al. (2015) for watersheds in northern and central Portugal, respectively. Due to these uncertainties surrounding socio-economic and land-use change scenarios, and their potentially high relevance, it is still difficult to generalize reservoir-scale impacts of global change for the Mediterranean.

Two findings of this study, however, seem to have much potential to be generalized, especially since they are consistent with those obtained for other supply systems in very different conditions. The first is that a decrease in water supply leads to changes in supply reliability rather than in total demand satisfaction, which translates as an increase in the frequency of agricultural droughts. Similar results were obtained for the water supply systems in the Ebro watershed (Martin-Carrasco and Garrote, 2007) and for aquifer-supplied systems in Spain, Portugal and Morocco (Stigter et al., 2014). The second is that most of the impacts are absorbed by losses to excess discharges and hydropower production, as a lower storage volume resulting from higher demands in dry years also allows capturing more water in wet years; this impact is also expected for reservoirs in Sardinia (Mereu et al., 2016) and Spain (Bangash et al., 2013).

\subsection{Implications for water management}

The results of this study point to a future increase in water scarcity and stress. However, in most scenarios, a moderate decrease in precipitation $(-10 \%)$ led to a moderate aggravation of present-day 
management problems, rather than to the occurrence of new and more severe problems. In fact, most scenarios pointed to lower demand satisfaction and higher exploitation, but maintaining already-existing levels of water scarcity (medium) and of water exploitation (severe stress); only a particularly negative combination of changes to land use, water demand and climate in scenario CS-A1B led to a change in scarcity level from medium to serious (Fig. 6). The same is true for siltation and trophic status: none of the scenarios indicated siltation problems in Vale do Gaio but all led to a worsening of the already existing eutrophication problems. Therefore, in the case of Vale do Gaio, water availability seems to be resilient to climate change; adaptation measures should focus on addressing already existing problems. In particular, the existing eutrophication problem also needs to be solved due to the implementation of the WFD, potentially allowing important synergies in designing and implementing future management measures.

These results also indicate that some of the conditions proposed in the socio-economic scenarios might not be sustainable in 2071-2100. In terms of water supply, the additional irrigation water demand might lead to serious water scarcity in climate scenario A1B (Fig. 6). As for water quality, both the additional water demand and the replacement of pasture by sunflower might be unsustainable, as they combine to increase P concentration by respectively lowering water volumes (Fig. 4) and increasing P inflows (Fig. 7). This would complicate achieving the aims of the WFD for P concentrations, which as stated above are already above the threshold for good water quality status.

This study also points to distinct impacts of climate as opposed to socio-economic changes. Although both do increase water demand, climate change decreases first and foremost the amount of water supply, while socio-economic change decreases its quality. This indicates that potential adaptation options should address land-use management at the watershed scale, as it could attenuate potential water quality issues and, at the same time, decrease water demand. For example, water demand could be decreased by changing the irrigated crop mix, as was illustrated by the present results of lower water consumption by olive trees when compared to rice; and water quality could be improved by lowering $P$ exports through a managed abandonment of pastures and re-wilding with forests or shrublands (Fig. 7).

Finally, adaptation measures have been linked to changes in the components of the water scarcity and exploitation indices by MartinCarrasco and Garrote (2007). For most scenarios with medium scarcity, the authors point to solutions in managing demand and better regulation of multi-year supplies, which could be concretized with e.g. better drought forecast, better operation rules for scarcity conditions, or an increase of storage volume. For the CS-A1B scenario, with serious scarcity, solutions could also involve water transfers from the Alqueva reservoir (a major regional water source as detailed earlier); in fact, the same can be argued for the other scenarios ( $\mathrm{C}$ and $\mathrm{CS}$ ), because of the very high water exploitation index (Fig. 6). Of course, the implied additional pressure on the Alqueva reservoir would need to be carefully considered through a regional scale analysis, and additional options such as decreasing irrigated areas might have to be considered.

\subsection{Uncertainties and future work}

This study illustrated the potential impacts of two climate and landuse change scenarios and their combinations on a single water supply reservoir in a dry Mediterranean region. Climate change impact assessment studies are normally hindered by uncertainties in the scenarios and the model itself, which can propagate uncertainty to the final results.

A first source of uncertainty is in the future emission of greenhouse gases and the climate sensitivity to these emissions (Collins et al., 2013; Stigter et al., 2014), This work used two emission scenarios but only one Global Circulation Model (GCM). However, it is difficult to directly compare these scenarios with GCM predictions for this region, since the range of rainfall predictions for 2071-2100 in this region is particularly large: between $+28 \%$ and $-50 \%$, with more variability attributable to differences between GCMs than to differences between scenarios (Miranda et al., 2006). This could be due to the location of the Iberian peninsula in the border between regions of increasing and decreasing rainfall scenarios (Collins et al., 2013), where GCM resolution could be too coarse to assess local changes.

It is therefore more accurate to compare the scenarios selected for this work with those derived using Regional Climate Models (RCMs) with higher resolution. The forecasts for scenario A1B represented a relatively small decrease when compared with the range of RCM predictions (between -8 and $-27 \%$ ) from project ENSEMBLES for this region (van der Linden and Mitchell, 2009), although half of the GCM forecasts were in a similar range to those from this work; the supplementary material has more information. The seasonal distribution roughly agreed with that of the ENSEMBLES models, although with a relatively later wet-season rainfall increase.

RCM projections also exist for scenarios A2 and B2 from project PRUDENCE (Christensen and Christensen, 2007) and for the more recent scenarios RCP4.5 and RCP8.5 from project EURO-CORDEX (Jacob et al., 2014). The more severe scenarios $A 2$ and RCP8.5 have similar ranges of change to $\mathrm{A} 1 \mathrm{~B}$ (respectively, -15 to $-35 \%$ and -11 to $-30 \%$ ), this despite RCP8.5 representing a more severe emission scenario; possibly this results from the improved performance of RCMs used in EURO-CORDEX when compared with earlier models (Kotlarski et al., 2014). Both PRUDENCE and EURO-CORDEX results also show winter rainfall increases. This indicates that the A1B scenario used in this work is also comparable to forecasts for RCP8.5, although close to the lower end, and lower than forecasts for A2. As for the less severe climate change scenarios, there are no RCM forecasts for the study area for scenario $\mathrm{B} 1$, but the $\mathrm{B} 1$ scenario used in this work is well within the range of both scenarios B2 ( 0 to $-15 \%)$ and RCP4.5 ( +2 to $-19 \%)$. Overall, the selected rainfall scenarios might underestimate the severity of rainfall changes, although they are still included the range of the newer RCP forecasts.

Another source of uncertainty is the downscaling of global climate projections to local conditions (Ehret et al., 2012; Maraun et al., 2010; Mourato et al., 2014). Statistical downscaling approaches can misrepresent future climate due to physical inconsistencies between temperature and rainfall values, difficulties in representing the daily structure of rainfall, or the underestimation of interannual variability (Maraun et al., 2010; Stigter et al., 2014). However, dynamic downscaling methods based on RCMs usually require some sort of bias correction which can also lead to physical inconsistencies and misrepresentation of daily patterns (Ehret et al., 2012; Flato et al., 2013; Maraun et al., 2010). This work tried to circumvent limitations in statistical downscaling by using only one climate predictor (sea level pressure) and past daily data to generate future series (Serpa et al., 2015), but this method could have led to lower inter-annual variability, especially in scenario B1 (Fig. 2); however, it should be noted that inter-annual variability in this work for scenario A1B was in line with that of the ENSEMBLES RCMs.

The simulation of hydrological response to climate change can also lead to uncertainties (Lespinas et al., 2014; Sellami et al., 2013).This issue was discussed in depth for this region by Serpa et al. (2015), which indicated that model uncertainty was decreased by the multi-objective calibration with several hydrological variables, and especially by the calibration with a long time series including extreme wet and dry years (Fig. 3). However, the use of average export rates to calibrate sediment, nitrogen and phosphorus exports increases the uncertainty for these results, as the model might not be accurate for the full range of crops, especially when considering that the model could not be calibrated to vegetation growth cycles adapted to higher temperatures and atmospheric $\mathrm{CO}_{2}$ concentrations (Nunes et al., 2008; Nunes and Seixas, 2011).

Finally, the selection of socio-economic scenarios can also induce important uncertainties (Molina-Navarro et al., 2014; Stigter et al., 
2015); for example, the same socio-economic storyline can lead to multiple societal responses (Stigter et al., 2015). Arguably, further work is needed with a broader range of scenarios, particularly to explore alternative land-use patterns. Some sort of standardized socio-economic scenarios (as already exist for climate) could be useful for this type of work, especially for comparison beyond the study region and for larger scale impacts assessment to underpin regional policies and planning; this can be based on the storylines already being developed for the current generation of socioeconomic scenarios (O'Neill et al., 2015). Recent projects such as MARS (Hering et al., 2015) and IMPRESSIONS (Harrison et al., 2016) have started to address this need. There is also a need for methods to address the uncertainty of different scenarios and overcome it to develop relevant adaptation measures (Girard et al., 2015).

Despite these uncertainties, a first understanding of at least the range of climate change impacts can be achieved by the use of a subset of different models or scenarios (Serpa et al., 2015), as shown by Nunes et al. (2008) and Stigter et al. (2014) for climate, or by Carvalho-Santos et al. (2016) for land use. This approach also allows the formulation of subsequent, more detailed studies which can address the most important uncertainties for each system.

This work also shows that more studies are needed for reservoirs with different characteristics (especially water demand and reservoir volume) to compare results and extract generalized principles. In particular, the relation between reservoir volume-to-inflow ratio and climate change impacts merits further attention as it is a potential indicator for the capacity of a given reservoir to absorb the impacts of lower streamflow by lowering excess discharge.

\section{Conclusions}

The results of this study indicate that the Vale do Gaio reservoir in the dry Mediterranean region could experience a moderate aggravation of water scarcity and stress issues in the future, due to a combination of lower streamflow caused by climate change, and increased water demands for irrigation caused by both climate and land use changes. However, water availability was shown to be resilient to the selected climate change scenarios, since the overall capacity of the system to satisfy irrigation demand did not decrease noticeably, although future scenarios did show decreases in supply reliability and higher ratios of exploitation of existing water supplies. This was due to the impacts of lower streamflow being largely absorbed by a decrease of excess discharge and fewer opportunities for hydropower production. The decrease in reliability with climate change and the role of excess discharge to counteract this are results which could be generalized to other reservoirs in the region.

In contrast, sediment and Phosphorus inflows into the reservoir increased, mostly influenced by land-use change. This was not sufficient to markedly impact reservoir siltation but would likely worsen the present-day trophic state, also due to lower water storage volumes in the reservoir. Higher P concentrations might complicate meeting the WFD targets for the reservoir.

Overall, the present results indicate that the Vale do Gaio water supply system is able to cope with climate change, as most impacts are an aggravation of issues which already occur in the present. The large volume of the reservoir in relation to streamflow appears to play an important role for this. Even so, a combination of more extreme climate changes together with unfavourable changes in socio-economic conditions could push the system across the threshold into serious water scarcity.

In terms of climate change adaptation, the present results indicate that solutions based on supply and demand management alone would be sufficient for most scenarios. The capacity of the Alqueva regional water reserve to handle water transfers under climate change is unknown, but might be required in the most extreme scenarios. On the other hand, adaptation solutions based on land-use change would seem the most effective to address reservoir water quality issues, and therefore territorial planning can play an important role for adaptation in this region.

Finally, this work shows that studies of the vulnerability of water supplies to climate change should go beyond assessing inflow quantity and quality and must also account for the reservoir's characteristics, especially its storage capacity and water demand. Therefore, further work is needed on systems with different characteristics across the Mediterranean, to derive general rules which could expedite the classification of vulnerability to climate change and the design of adaptation measures.

\section{Acknowledgements}

This work was funded by the Portuguese Foundation for Science and Technology within the framework of project ERLAND: "Direct and indirect impacts of climate change on soil erosion and land degradation in Mediterranean watersheds" (FCOMP-01-0124-FEDER-008534), the post-doctoral fellowships attributed to J.P. Nunes (SFRH/BPD/39721/ 2007 and SFRH/BPD/87571/2012), and funding for the CESAM centre (UID/AMB/50017), co-funded by the European Social Fund and the European Regional Development Fund within the PT2020 Partnership Agreement and Compete 2020.

\section{Appendix A. Supplementary data}

Supplementary data to this article can be found online at http://dx. doi.org/10.1016/j.scitotenv.2017.01.131.

\section{References}

Alcamo, J., Döll, P., Henrichs, T., Kaspar, F., Lehner, B., Rösch, T., Siebert, S., 2003. Global estimates of water withdrawals and availability under current and future "business-asusual" conditions. Hydrol. Sci. J. 48:339-348. http://dx.doi.org/10.1623/hysj.48.3.339. 45278.

APA, 2014a. SNIRH: Sistema Nacional de Informação de Recursos Hídricos [WWW Document]. URL http://snirh.pt

APA, 2014b. INSAAR: Inventário Nacional de Sistemas de Abastecimento de Águas e de Águas Residuais [WWW Document]. URL http://insaar.apambiente.pt/

Bangash, R.F., Passuello, A., Sanchez-Canales, M., Terrado, M., López, A., Elorza, F.J., Ziv, G., Acuña, V., Schuhmacher, M., 2013. Ecosystem services in Mediterranean river basin: climate change impact on water provisioning and erosion control. Sci. Total Environ. 458-460:246-255. http://dx.doi.org/10.1016/j.scitotenv.2013.04.025.

Booij, M.J., 2003. Determination and integration of appropriate spatial scales for river basin modelling. Hydrol. Process. 17:2581-2598. http://dx.doi.org/10.1002/hyp.1268.

Buendia, C., Bussi, G., Tuset, J., Vericat, D., Sabater, S., Palau, A., Batalla, R.., 2016. Effects of afforestation on runoff and sediment load in an upland Mediterranean catchment. Sci. Total Environ. 540:144-157. http://dx.doi.org/10.1016/j.scitotenv.2015.07.005.

Bussi, G., Francés, F., Horel, E., López-Tarazón, J.A., Batalla, R.J., 2014. Modelling the Impact of Climate Change on Sediment Yield in a Highly Erodible Mediterranean Catchment. 14:pp. 1921-1937. http://dx.doi.org/10.1007/s11368-014-0956-7.

Bussi, G., Dadson, S.J., Prudhomme, C., Whitehead, P.G., 2016a. Modelling the future impacts of climate and land-use change on suspended sediment transport in the River Thames (UK). J. Hydrol. 542:357-372. http://dx.doi.org/10.1016/j.jhydrol.2016.09. 010

Bussi, G., Whitehead, P.G., Bowes, M.J., Read, D.S., Prudhomme, C., Dadson, S.J., 2016b. Impacts of climate change, land-use change and phosphorus reduction on phytoplankton in the River Thames (UK). Sci. Total Environ. 572:1507-1519. http://dx.doi.org/ 10.1016/j.scitotenv.2016.02.109.

Cardoso, J.V.J.C., 1965. Os solos de Portugal, sua classificação, caracterização e génese: 1- a sul do rio Tejo. Direcção-Geral dos Servíços Agrícolas, Lisbon.

Cardoso, J.C., Bessa, M.T., Marado, M.B., 1973. Carta dos solos de Portugal - 1:1.000.000. Agron. Lusit. 33, 481-602.

Carvalho-Santos, C., Nunes, J.P., Monteiro, A.T., Hein, L., Honrado, J.P., 2016. Assessing the effects of land cover and future climate conditions on the provision of hydrological services in a medium-sized watershed of Portugal. Hydrol. Process. 30:720-738. http://dx.doi.org/10.1002/hyp.10621.

Cerdan, O., Govers, G., Le Bissonnais, Y., Van Oost, K., Poesen, J., Saby, N., Gobin, A., Vacca, A., Quinton, J., Auerswald, K., Klik, A., Kwaad, F.J.P.M., Raclot, D., Ionita, I., Rejman, J., Rousseva, S., Muxart, T., Roxo, M.J., Dostal, T., 2010. Rates and spatial variations of soil erosion in Europe: a study based on erosion plot data. Geomorphology 122: 167-177. http://dx.doi.org/10.1016/j.geomorph.2010.06.011.

Christensen, J.H., Christensen, O.B., 2007. A summary of the PRUDENCE model projections of changes in European climate by the end of this century. Clim. Chang. 81:7-30. http://dx.doi.org/10.1007/s10584-006-9210-7.

Collins, M., Knutti, R., Arblaster, J., Dufresne, J.-L., Fichefet, T., Friedlingstein, P., Gao, X., Gutowski, W.J., Johns, T., Krinner, G., Shongwe, M., Tebaldi, C., Weaver, A.J., Wehner, M., 2013. Long-term climate change: projections, commitments and irreversibility. 
In: Stocker, T.F., Qin, D., Plattner, G.-K., Tignor, M., Allen, S.K., Boschung, J., Nauels, A., Xia, Y., Bex, V., Midgley, P.M. (Eds.), Climate Change 2013: The Physical Science Basis. Contribution of Working Group I to the Fifth Assessment Report of the Intergovernmental Panel on Climate Change. Cambridge University Press, Cambridge and New York:pp. 1029-1136 http://dx.doi.org/10.1017/CBO9781107415324.024.

Connell-Buck, C.R., Medellín-Azuara, J., Lund, J.R., Madani, K., 2011. Adapting California's water system to warm vs. dry climates. Clim. Change 109:S133-S149. http://dx.doi. org/10.1007/s10584-011-0302-7.

de Vente, J., Poesen, J., Bazzoffi, P., Van Rompaey, A., Verstraeten, G., 2006. Predicting catchment sediment yield in mediterranean environments: the importance of sediment sources and connectivity in Italian drainage basins. Earth Surf. Process. Landf. 31:1017-1034. http://dx.doi.org/10.1002/esp.1305.

Diogo, P.A.M., 2008. Fontes de fósforo total e o estado trófico de albufeiras em Portugal Continental. MSc Thesis. New University of Lisbon, Lisbon.

Domingos, T., Vieira, R.S., Teixeira, C.M.G.L., Canaveira, P., Marta-Pedroso, C., 2013. Avaliação Ambiental Estratégica dos novos investimentos do EFMA relativos à Rede Secundária de Rega no âmbito do INALENTEJO. Relatório Final: Relatório Ambiental. Instituto Superior Técnico, Universidade de Lisboa, Lisbon.

EEA, 2002. CORINE Land Cover Update, I \& CLC2000 Project, Technical Guidelines. European Environmental Agency (EEA), Copenhagen.

EEA, 2012. Water resources in Europe in the context of vulnerability. EEA 2012 State of Water Assessment. EEA Report no. 11/2012. European Environmental Agency (EEA), Copenhagen.

Ehret, U., Zehe, E., Wulfmeyer, V., Warrach-Sagi, K., Liebert, J., 2012. HESS opinions "Should we apply bias correction to global and regional climate model data?". Hydrol. Earth Syst. Sci. 16:3391-3404. http://dx.doi.org/10.5194/hess-16-3391-2012.

Flato, G., Marotzke, J., Abiodun, B., Braconnot, P., Chou, S.C., Collins, W., Cox, P., Driouech, F., Emori, S., Eyring, V., Forest, C., Gleckler, P., Guilyardi, E., Jakob, C., Kattsov, V., Reason, C., Rummukainen, M., 2013. Evaluation of climate models. In: Stocker, T.F., Qin, D., Plattner, G.-K., Tignor, M., Allen, S.K., Boschung, J., Nauels, A., Xia, Y., Bex, V., Midgley, P.M. (Eds.), Climate Change 2013: The Physical Science Basis. Contribution of Working Group I to the Fifth Assessment Report of the Intergovernmental Panel on Climate Change. Cambridge University Press, Cambridge and New York: pp. 741-866 http://dx.doi.org/10.1017/CBO9781107415324.020.

García-Ruiz, J.M., López-Moreno, I.I., Vicente-Serrano, S.M., Lasanta-Martínez, T., Beguería, S., 2011. Mediterranean water resources in a global change scenario. Earth Sci. Rev. 105:121-139. http://dx.doi.org/10.1016/j.earscirev.2011.01.006.

Garrote, L., Granados, A., Iglesias, A., 2016. Strategies to reduce water stress in Euro-Mediterranean river basins. Sci. Total Environ. 543:997-1009. http://dx.doi.org/10.1016/j. scitotenv.2015.04.106.

Gilmanov, T.G., Soussana, J.F., Aires, L., Allard, V., Ammann, C., Balzarolo, M., Barcza, Z., Bernhofer, C., Campbell, C.L., Cernusca, A., Cescatti, A., Clifton-Brown, J., Dirks, B.O.M., Dore, S., Eugster, W., Fuhrer, J., Gimeno, C., Gruenwald, T., Haszpra, L. Hensen, A., Ibrom, A., Jacobs, A.F.G., Jones, M.B., Lanigan, G., Laurila, T., Lohila, A., Manca, G., Marcolla, B., Nagy, Z., Pilegaard, K., Pinter, K., Pio, C., Raschi, A., Rogiers, N., Sanz, M.J., Stefani, P., Sutton, M., Tuba, Z., Valentini, R., Williams, M.L., Wohlfahrt, G., 2007. Partitioning European grassland net ecosystem CO2 exchange into gross primary productivity and ecosystem respiration using light response function analysis. Agric. Ecosyst. Environ. 121:93-120. http://dx.doi.org/10.1016/j.agee.2006.12.008.

Girard, C., Pulido-Velazquez, M., Rinaudo, J.-D., Pagé, C., Caballero, Y., 2015. Integrating top-down and bottom-up approaches to design global change adaptation at the river basin scale. Glob. Environ. Chang. 34:132-146. http://dx.doi.org/10.1016/j. gloenvcha.2015.07.002

Harrison, P.A., Dunford, R.W., Holman, I.P., Rounsevell, M.D.A., 2016. Climate change impact modelling needs to include cross-sectoral interactions. Nat. Clim. Chang. 6: 885-890. http://dx.doi.org/10.1038/nclimate3039.

Hawtree, D., Nunes, J.P., Keizer, J.J., Jacinto, R., Santos, J., Rial-Rivas, M.E., Boulet, A.K. Tavares-Wahren, F., Feger, K.H., 2015. Time series analysis of the long-term hydrologic impacts of afforestation in the Águeda watershed of north-Central Portugal. Hydrol. Earth Syst. Sci. 19:3033-3045. http://dx.doi.org/10.5194/hess-19-3033-2015.

Hay, L.E., Wilby, R.L., Leavesley, G.H., 2000. A comparison of delta change and downscaled GCM scenarios for three mountainous basins in the United States. J. Am. Water Resour. Assoc. 36:387-397. http://dx.doi.org/10.1111/j.1752-1688.2000.tb04276.x.

Hering, D., Carvalho, L., Argillier, C., Beklioglu, M., Borja, A., Cardoso, A.C., Duel, H., Ferreira, T., Globevnik, L., Hanganu, J., Hellsten, S., Jeppesen, E., Kodes, V., Solheim, A.L., Nõges, T., Ormerod, S., Panagopoulos, Y., Schmutz, S., Venohr, M., Birk, S., 2015. Managing aquatic ecosystems and water resources under multiple stress - an introduction to the MARS project. Sci. Total Environ. 503-504:10-21. http://dx.doi.org/10.1016/j. scitotenv.2014.06.106.

Iglesias, A., Garrote, L., Diz, A., Schlickenrieder, J., Martin-Carrasco, F., 2011. Re-thinking water policy priorities in the Mediterranean region in view of climate change. Environ. Sci. Pol. 14:744-757. http://dx.doi.org/10.1016/j.envsci.2011.02.007.

INAG, 2009. Critérios Para a Classificação do estado das massas de água superficiais - rios e albufeiras. Instituto da Água (INAG), Lisbon.

INE, 2011. Recenseamento Agrícola 2009. Análise dos Principais Resultados. Instituto Nacional de Estatística (INE), Lisbon.

INIA, 2000. Manual de fertilização das culturas. Instituto Nacional de Investigação Agrária (INIA). Laboratório Químico Agrícola Rebelo da Silva (INIA-LQARS), Lisbon.

Jacinto, R., Cruz, M.J., Santos, F.D., 2013. Development of water use scenarios as a tool for adaptation to climate change. Drink. Water Eng. Sci. Discuss. 6:61-68. http://dx.doi. org/10.5194/dwes-6-61-2013.

Jacob, D., Petersen, J., Eggert, B., Alias, A., Christensen, O.B., Bouwer, L.M., Braun, A., Colette, A., Déqué, M., Georgievski, G., Georgopoulou, E., Gobiet, A., Menut, L., Nikulin, G., Haensler, A., Hempelmann, N., Jones, C., Keuler, K., Kovats, S., Kröner, N., Kotlarski, S., Kriegsmann, A., Martin, E., van Meijgaard, E., Moseley, C., Pfeifer, S., Preuschmann, S., Radermacher, C., Radtke, K., Rechid, D., Rounsevell, M.,
Samuelsson, P., Somot, S., Soussana, J.F., Teichmann, C., Valentini, R., Vautard, R., Weber, B., Yiou, P., 2014. EURO-CORDEX: new high-resolution climate change projections for European impact research. Reg. Environ. Chang. 14:563-578. http://dx.doi. org/10.1007/s10113-013-0499-2.

Jarvis, A., Reuter, H.I., Nelson, A., Guevara, E., 2006. Hole-filled Seamless SRTM data V3 [WWW Document]. URL srtm.csi.cgiar.org

Kotlarski, S., Keuler, K., Christensen, O.B., Colette, A., Déqué, M., Gobiet, A., Goergen, K. Jacob, D., Lüthi, D., Van Meijgaard, E., Nikulin, G., Schär, C., Teichmann, C., Vautard, R., Warrach-Sagi, K., Wulfmeyer, V., 2014. Regional climate modeling on European scales: a joint standard evaluation of the EURO-CORDEX RCM ensemble. Geosci. Model Dev. 7:1297-1333. http://dx.doi.org/10.5194/gmd-7-1297-2014.

Kovats, R.S.S., Valentini, R., Bouwer, L.M.L.M., Georgopoulou, E., Jacob, D., Martin, E. Rounsevell, M., Soussana, J.-F.J.-F., 2014. Europe. In: Barros, V.R., Field, C.B., Dokken, D.J., Mastrandrea, M.D., Mach, K.J., Bilir, T.E., Chatterjee, M., Ebi, K.L., Estrada, Y.O. Genova, R.C., Girma, B., Kissel, E.S., Levy, A.N., MacCracken, S., Mastrandrea, P.R., White, L.L. (Eds.), Climate Change 2014: Impacts, Adaptation, and Vulnerability. Part B: Regional Aspects. Contribution of Working Group II to the Fifth Assessment Report of the Intergovernmental Panel on Climate Change. Cambridge University Press, Cambridge and New York, pp. 1267-1326.

Lane, L.J., Hernandez, M., Nichols, M., 1997. Processes controlling sediment yield from watersheds as functions of spatial scale. Environ. Model. Softw. 12:355-369. http://dx doi.org/10.1016/S1364-8152(97)00027-3.

Lespinas, F., Ludwig, W., Heussner, S., 2014. Hydrological and climatic uncertainties associated with modeling the impact of climate change on water resources of small Mediterranean coastal rivers. J. Hydrol. 511:403-422. http://dx.doi.org/10.1016/j.jhydrol. 2014.01.033.

Li, Z., Fang, H., 2016. Impacts of climate change on water erosion: a review. Earth Sci. Rev. 163:94-117. http://dx.doi.org/10.1016/j.earscirev.2016.10.004

López-Moreno, J.I., Zabalza, J., Vicente-Serrano, S.M., Revuelto, J., Gilaberte, M., AzorinMolina, C., Morán-Tejeda, E., García-Ruiz, J.M., Tague, C., 2014. Impact of climate and land use change on water availability and reservoir management: scenarios in the Upper Aragón River, Spanish Pyrenees. Sci. Total Environ. 493:1222-1231. http://dx.doi.org/10.1016/j.scitotenv.2013.09.031.

Ludwig, R., Roson, R., 2016. Climate change, water and security in the Mediterranean: introduction to the special issue. Sci. Total Environ. 543:847-850. http://dx.doi.org/10 1016/j.scitotenv.2015.10.142.

Majone, B., Villa, F., Deidda, R., Bellin, A., 2016. Impact of climate change and water use policies on hydropower potential in the south-eastern Alpine region. Sci. Total Environ. 563:965-980. http://dx.doi.org/10.1016/j.scitotenv.2015.05.009.

Maraun, D., Wetterhall, F., Ireson, A.M., Chandler, R.E., Kendon, E.J., Widmann, M., Brienen, S., Rust, H.W., Sauter, T., Themeßl, M., Venema, V.K.C., Chun, K.P., Goodess, C.M., Jones, R.G., Onof, C., Vrac, M., Thiele-Eich, I., 2010. Precipitation downscaling under climate change: recent developments to bridge the gap between dynamical models and the end user. Rev. Geophys. 48, RG3003. http:// dx.doi.org/10.1029/2009rg000314.

Martin-Carrasco, F., Garrote, L., 2007. Drought-induced water scarcity in water resources systems. In: Vasiliev, O.F., van Gelder, P.H.A.J.M., Plate, E.J., Bolgov, M.V. (Eds.), Extreme Hydrological Events: New Concepts for Security. Springer, Dordrecht: pp. 301-311 http://dx.doi.org/10.1007/978-1-4020-5741-0_20.

Medellín-Azuara, J., Howitt, R.E., MacEwan, D.J., Lund, J.R., 2011. Economic impacts of climate-related changes to California agriculture. Clim. Chang. 109:S387-S405. http:// dx.doi.org/10.1007/s10584-011-0314-3.

Mereu, S., Sušnik, J., Trabucco, A., Daccache, A., Vamvakeridou-Lyroudia, L., Renoldi, S. Virdis, A., Savić, D., Assimacopoulos, D., 2016. Operational resilience of reservoirs to climate change, agricultural demand, and tourism: a case study from Sardinia. Sci. Total Environ. 543:1028-1038. http://dx.doi.org/10.1016/j.scitotenv.2015.04.066.

Middleton, N., Thomas, D., 1997. World Atlas of Desertification, 2nd. editio. ed. UNEP: United Nations Environment Program, London.

Miranda, P.M.A., Valente, M.A., Tomé, A.R., Trigo, R., Coelho, M.F.E.S., Aguiar, A., Azevedo E.B., 2006. 2. O Clima de Portugal nos Séculos XX e XXI. In: Santos, F.D., Miranda, P. (Eds.), Alterações Climáticas Em Portugal: Cenários, Impactos E Medidas de Adaptação. Projecto SIAM II. Gradiva - Publicações, Lisbon, pp. 45-113.

Molina-Navarro, E., Trolle, D., Martínez-Pérez, S., Sastre-Merlín, A., Jeppesen, E., 2014. Hydrological and water quality impact assessment of a Mediterranean limno-reservoir under climate change and land use management scenarios. J. Hydrol. 509:354-366. http://dx.doi.org/10.1016/j.jhydrol.2013.11.053.

Moriasi, D.N., Arnold, J.G., Van Liew, M.W., Bingner, R.L., Harmel, R.D., Veith, T.L., 2007 Model evaluation guidelines for systematic quantification of accuracy in watershed simulations. Trans. ASABE 50:885-900. http://dx.doi.org/10.13031/2013.23153.

Mourato, S., Moreira, M., Corte-Real, J., 2014. Water availability in southern Portugal for different climate change scenarios subjected to bias correction. J. Urban Environ. Eng. 8:109-117. http://dx.doi.org/10.4090/juee.2014.v8n1.109117.

Mourato, S., Moreira, M., Corte-Real, J., 2015. Water resources impact assessment under climate change scenarios in Mediterranean watersheds. Water Resour. Manag. 29: 2377-2391. http://dx.doi.org/10.1007/s11269-015-0947-5.

Nakicenovic, N., Swart, R., 2000. Special report on emissions scenarios. A Special Report of Working Group III of the Intergovernmental Panel on Climate Change. Cambridge University Press, Cambridge.

Neitsch, S.L., Arnold, J.G., Kiniry, J.R., Srinivasan, R., Williams, J.R., 2010. Soil and water assessment tool. Input/Output File Documentation, Version 2009. Texas A\&M University System, College Station.

Neitsch, S.L., Arnold, J.G., Kiniry, J.R., Williams, J.R., 2011. Soil and water assessment tool. Theoretical Documentation, Version 2009 (TR-406). Texas A\&M University System, College Station.

Nunes, J.P., Seixas, J., 2011. Modelling the impacts of climate change on water balance and agricultural and forestry productivity in southern Portugal using SWAT. In: Shukla, 
M.K. (Ed.), Soil Hydrology, Land-Use and Agriculture. Measurement and Modelling. CABI, Wallingford, pp. 366-383.

Nunes, J.P., Seixas, J., Pacheco, N.R., 2008. Vulnerability of water resources, vegetation productivity and soil erosion to climate change in Mediterranean watersheds. Hydrol. Process. 22:3115-3134. http://dx.doi.org/10.1002/hyp.6897.

Nunes, J.P., Seixas, J., Keizer, J.J., Ferreira, A.J.D., 2009. Sensitivity of runoff and soil erosion to climate change in two Mediterranean watersheds. Part II: assessing impacts from changes in storm rainfall, soil moisture and vegetation cover. Hydrol. Process. 23: 1212-1220. http://dx.doi.org/10.1002/hyp.7250.

Nunes, J.P., Seixas, J., Keizer, J.J., 2013. Modeling the response of within-storm runoff and erosion dynamics to climate change in two Mediterranean watersheds: a multimodel, multi-scale approach to scenario design and analysis. Catena 102:27-39. http://dx.doi.org/10.1016/j.catena.2011.04.001.

O'Neill, B.C., Kriegler, E., Riahi, K., Ebi, K.L., Hallegatte, S., Carter, T.R., Mathur, R., van Vuuren, D.P., 2014. A New Scenario Framework for Climate Change Research: the Concept of Shared Socioeconomic Pathways 387-400. http://dx.doi.org/10.1007/ s10584-013-0905-2.

O'Neill, B.C., Kriegler, E., Ebi, K.L., Kemp-Benedict, E., Riahi, K., Rothman, D.S., van Ruijven, B.J., van Vuuren, D.P., Birkmann, J., Kok, K., Levy, M., Solecki, W., 2015. The roads ahead: narratives for shared socioeconomic pathways describing world futures in the 21st century. Glob. Environ. Chang. http://dx.doi.org/10.1016/j.gloenvcha.2015. 01.004 .

Paredes, J., Andreu, J., Solera, A., 2010. A decision support system for water quality issues in the Manzanares River. Sci. Total Environ. 408:2576-2589. http://dx.doi.org/10. 1016/j.scitotenv.2010.02.037.

Paredes-Arquiola, J., Andreu-Álvarez, J., Martín-Monerris, M., Solera, A., 2010. Water quantity and quality models applied to the Jucar River Basin, Spain. Water Resour. Manag. 24:2759-2779. http://dx.doi.org/10.1007/s11269-010-9578-z.

Piras, M., Mascaro, G., Deidda, R., Vivoni, E.R., 2014. Quantification of hydrologic impacts of climate change in a Mediterranean basin in Sardinia, Italy, through high-resolution simulations. Hydrol. Earth Syst. Sci. 18:5201-5217. http://dx.doi.org/10.5194/hess18-5201-2014.

Pulido-Velazquez, D., García-Aróstegui, J.L., Molina, J.-L., Pulido-Velazquez, M., 2015a. Assessment of future groundwater recharge in semi-arid regions under climate change scenarios (Serral-Salinas aquifer, SE Spain). Could increased rainfall variability increase the recharge rate? Hydrol. Process. 29:828-844. http://dx.doi.org/10.1002/ hyp.10191.

Pulido-Velazquez, M., Peña-Haro, S., García-Prats, A., Mocholi-Almudever, A.F. Henriquez-Dole, L., Macian-Sorribes, H., Lopez-Nicolas, A., 2015b. Integrated assessment of the impact of climate and land use changes on groundwater quantity and quality in the Mancha Oriental system (Spain). Hydrol. Earth Syst. Sci. 19: 1677-1693. http://dx.doi.org/10.5194/hess-19-1677-2015.

Rial-Rivas, M.E., 2007. Investigación dos procesos que regulan o caudal e a calidade das augas na bacía do río Anllóns. PhD thesis. University of Santiago de Compostela, Santiago de Compostela.

Rodriguez-Lloveras, X., Bussi, G., Francés, F., Rodriguez-Caballero, E., Solé-benet, A., Calle M., Benito, G., 2015. Patterns of runoff and sediment production in response to landuse changes in an ungauged Mediterranean catchment. J. Hydrol. 531:1054-1066. http://dx.doi.org/10.1016/j.jhydrol.2015.11.014.
Rodriguez-Lloveras, X., Buytaert, W., Benito, G., 2016. Land use can offset climate change induced increases in erosion in Mediterranean watersheds. Catena 143:244-255. http://dx.doi.org/10.1016/j.catena.2016.04.012.

Sellami, H., La Jeunesse, I., Benabdallah, S., Vanclooster, M., 2013. Parameter and rating curve uncertainty propagation analysis of the SWAT model for two small Mediterranean catchments. Hydrol. Sci. J. 58:1635-1657. http://dx.doi.org/10.1080/02626667. 2013.837222 .

Sellami, H., Benabdallah, S., Jeunesse, I. La, Vanclooster, M., 2016. Quantifying hydrological responses of small Mediterranean catchments under climate change projections. Sci. Total Environ. 543:924-936. http://dx.doi.org/10.1016/j.scitotenv.2015.07.006.

Serpa, D., Nunes, J.P., Santos, J., Sampaio, E., Jacinto, R., Veiga, S., Lima, J.C., Moreira, M., Corte-Real, J., Keizer, J.J., Abrantes, N., 2015. Impacts of climate and land use changes on the hydrological and erosion processes of two contrasting Mediterranean catchments. Sci. Total Environ. 538:64-77. http://dx.doi.org/10.1016/j.scitotenv.2015.08. 033.

Simonneaux, V., Cheggour, A., Deschamps, C., Mouillot, F., Cerdan, O., Le Bissonnais, Y., 2015. Land use and climate change effects on soil erosion in a semi-arid mountainous watershed (High Atlas, Morocco). J. Arid Environ. 122:64-75. http://dx.doi.org/10. 1016/j.jaridenv.2015.06.002.

Stefanova, A., Krysanova, V., Hesse, C., Lillebø, A.I., 2015. Climate change impact assessment on water inflow to a coastal lagoon: the Ria de Aveiro watershed, Portugal. Hydrol. Sci. J. 60:929-948. http://dx.doi.org/10.1080/02626667.2014.983518.

Stigter, T.Y., Nunes, J.P., Pisani, B., Fakir, Y., Hugman, R., Li, Y., Tomé, S., Ribeiro, L., Samper, J., Oliveira, R., Monteiro, J.P., Silva, A., Tavares, P.C.F., Shapouri, M., Cancela da Fonseca, L., El Himer, H., 2014. Comparative assessment of climate change and its impacts on three coastal aquifers in the Mediterranean. Reg. Environ. Chang. 14:41-56. http://dx. doi.org/10.1007/s10113-012-0377-3.

Stigter, T.Y., Varanda, M., Bento, S., Nunes, J.P., Hugman, R., 2015. Combined assessment of climate change and socio-economic development as drivers of freshwater availability in the south of Portugal. Water Resour. Manag. http://dx.doi.org/10.1007/s11269015-0994-y.

UÉ, 2014. Centro de Geofísica de Évora [WWW Document]. URL http://www.cge.uevora. pt/

van der Linden, P., Mitchell, J.F.B., 2009. ENSEMBLES: Climate Change and its Impacts: Summary of Research and Results from the ENSEMBLES Project. Met Office Hadley Centre, Exeter.

van Vuuren, D.P., Riahi, K., Moss, R., Edmonds, J., Thomson, A., Nakicenovic, N., Kram, T., Berkhout, F., Swart, R., Janetos, A., Rose, S.K., Arnell, N., 2012. A proposal for a new scenario framework to support research and assessment in different climate research communities. Glob. Environ. Chang. 22:21-35. http://dx.doi.org/10.1016/j. gloenvcha.2011.08.002.

Verheijen, F.G.A., Jones, R.J.A., Rickson, R.J., Smith, C.J., Bastos, A.C., Nunes, J.P., Keizer, J.J., 2012. Concise overview of European soil erosion research and evaluation. Acta Agric. Scand. Sect. B Soil Plant Sci. 62:185-190. http://dx.doi.org/10.1080/09064710. 2012.697573. 